\title{
Comparison of haemocytic parameters among flat oyster Ostrea edulis stocks with different susceptibility to bonamiosis and the Pacific oyster Crassostrea gigas
}

\author{
Pilar Comesaña ${ }^{a}$, Sandra M. Casas ${ }^{a, 1}$, Asunción Cao $^{a}$, Elvira Abollo ${ }^{a, 2}$, Isabelle Arzul ${ }^{b}$, Benjamin \\ Morga ${ }^{b}$, Antonio Villalba ${ }^{a, *}$
}

a Centro de Investigacións Mariñas, Consellería do Mar, Xunta de Galicia, Aptdo. 13, E-36620

Vilanova de Arousa, Spain

b Laboratoire de Génétique et Pathologie, IFREMER, OIE Reference Laboratory for Marteiliosis and Bonamiosis, 17390 La Tremblade, France

\footnotetext{
${ }^{1}$ Present address: Department of Veterinary Science, Louisiana State University, Baton Rouge, LA 70803, USA.

${ }^{2}$ Present address: Fundación CETMAR - Centro Tecnológico del Mar, Eduardo Cabello s/n, 36208

Vigo, Spain.
}

*: Corresponding author : A. Villalba, email address : villalba@cimacoron.org

\begin{abstract}
:
Farming of the flat oyster Ostrea edulis in Europe is severely constrained by the protozoan Bonamia ostreae. The introduction of the resistant species Crassostrea gigas has been a relief for the farmers, while the pilot programmes to select $O$. edulis strains resistant to bonamiosis performed in various countries can be seen as a promising strategy to minimise the effects of bonamiosis. However, the physiological bases of this differential susceptibility remain unknown. A search for an explanation of the intra and interspecific differences in oyster susceptibility to bonamiosis was accomplished by comparing some immune parameters among various O. edulis stocks and C. gigas. On December 2003, naïve and Bonamia-relatively resistant flat oysters from Ireland, Galician flat oysters and Pacific oysters $C$. gigas were deployed in a Galician area affected by bonamiosis; haemolymph samples were taken in February and May 2004. A new oyster deployment at the same place was carried out on June 2004 and haemolymph sampling was performed on April 2005. On November 2004, new sets of Irish flat oysters and C. gigas were deployed in Ireland and haemolymph sampling was performed in June 2005. Various haemocytic parameters were measured: total and differential haemocyte count, phagocytic ability, respiratory burst (superoxide anion [ $\left.\mathrm{O}_{2}^{-}\right]$and hydrogen peroxide $\left[\mathrm{H}_{2} \mathrm{O}_{2}\right]$ ) and nitric oxide [NO] production. The comparison of the parameters was carried out at 3 levels: (1) between $O$. edulis and $C$. gigas, (2) among $O$. edulis stocks with different susceptibility to bonamiosis, and (3) between Bonamia-infected and non infected $O$. edulis. In addition, haemocyte- $B$. ostreaein vitro encounters were performed to analyse interspecific differences in the haemocytic respiratory burst, using flow cytometry. Significant differences associated with total and differential haemocyte count, and respiratory burst between $O$. edulis and $C$. gigas were detected, which could be linked to differences in susceptibility to bonamiosis between both species. Additionally, significant changes in total and differential haemocyte count, and respiratory burst of $O$. edulis associated with $B$. ostreae infection were found. However, no consistent difference in any haemocyte parameter between the $O$. edulis stocks involved in the study was recorded.
\end{abstract}




\section{Graphical abstract}

Distribution (percentage) of haemocytes of Ostrea edulis (left) and Crassostrea gigas (right) into classes of null, medium and high reactive oxygen species production, corresponding to three treatments: control, addition of 5 B. ostreae cells per haemocyte (B:h 5:1), and addition of $10 B$. ostreae cells per haemocyte (B:h 10:1). Bar height represents mean (SE) percentage of cells.

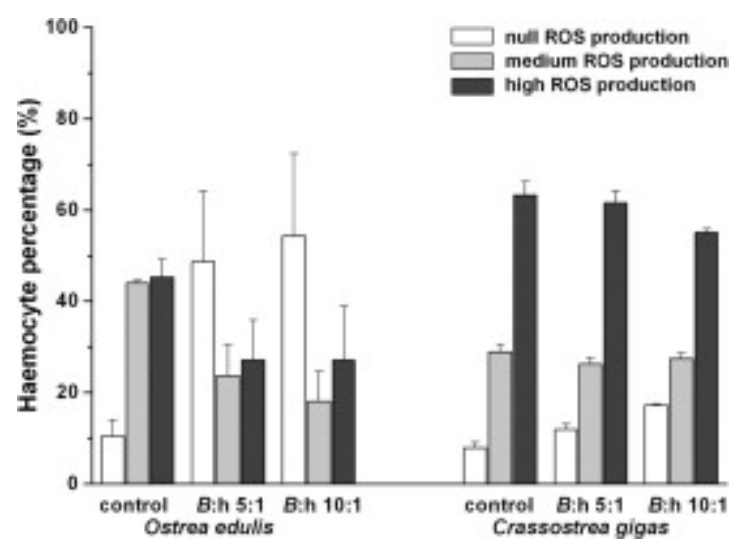

\section{Highlights}

Differences in THC, DHC and respiratory burst between oyster species were found. Bonamia ostreae affects THC, DHC and respiratory burst of Ostrea edulis. No studied parameter explained differences in susceptibility between $O$. edulis stocks.

Keywords: Ostrea edulis; Crassostrea gigas; Bonamia ostreae; Haemocyte; Phagocytosis; Respiratory burst; Nitric oxide 


\section{Introduction}

Farming of the flat oyster Ostrea edulis in Europe is severely constrained by an infection caused by the haplosporidian protozoan Bonamia ostreae (Pichot et al. 1980). The flat oyster has been replaced with the Pacific oyster, Crassostrea gigas, a resistant species to bonamiosis (Culloty et al., 1999; Renault et al., 1995), in many European affected areas, after the first outbreaks in late 1970s. Relatively resistant flat oyster strains, with higher survival rates, have been reported deriving from either natural (da Silva et al., 2005; Elston et al., 1987) or human selection (Culloty et al., 2001, 2004; Hervio et al., 1995; Naciri-Graven et al., 1999). The differences in susceptibility to bonamiosis among Ostrea edulis strains could be related to differences in the defence system (Cochennec et al., 1995; Cochennec-Laureau et al., 2003; Naciri-Graven et al., 1998).

The immune function of molluscs is based on innate mechanisms of cellular and humoral defence, both operating in coordination to recognise and eliminate foreign microorganisms (Cheng, 2000, Chu, 2000, Faisal et al., 1998 Mitta et al., 2000). Cellular defence in bivalve molluscs relies on haemocytes (Adema et al., 1991a; Cheng, 1981, 1996). Consistently, the concentration of these cells in the haemolymph, usually expressed as total haemocyte count (THC), is influenced by different pathogens (Allam et al., 2001; da Silva et al., 2008; La Peyre et al., 1995; Parry and Pipe, 2004). Morphological differences among haemocytes, probably associated with differential functionality, have led some to consider haemocyte subpopulations (Auffret, 1989; Cheng, 1996; Hine, 1999). In O. edulis and C. gigas, two major kinds of cells can be distinguished in the haemolymph, granulocytes and hyalinocytes, the latter being divided into large and small according their size (Bachère et al., 1991; CochennecLaureau et al., 2003; La Peyre et al., 1995; Renault et al., 2001; Xue et al., 2000). The relative abundance of each type in the haemolymph is termed the differential haemocyte count (DHC) and it is influenced by some pathogens (Allam et al., 2006; Oubella et al., 1996; Reid et al., 2003).

Phagocytosis is the principal cell defence mechanism to get rid of pathogens of small size in invertebrates (Bachère et al., 1995; Cheng, 1981, Feng, 1988). Once the pathogen is internalised a rise of oxygen consumption, named respiratory burst, may be triggered, generating a set of reactive oxygen species (ROS) with antimicrobial properties (Adema et al., 1991a; Babior, 1997; Kimura et al., 2005). Superoxide anion $\left(\mathrm{O}_{2}\right)$, the first metabolite formed, is transformed spontaneously or via the superoxide dismutase into hydrogen peroxide $\left(\mathrm{H}_{2} \mathrm{O}_{2}\right)$ (Babior, 1997; Badwey and Karnovsky, 1980; Reeves, 2003; Roos et al., 2003). Alternatively, $\mathrm{H}_{2} \mathrm{O}_{2}$ can be degraded to oxygen and water in a catalase-dependent reaction or can combine with chloride $\left(\mathrm{Cl}^{-}\right)$to form hypochlorous acid in a reaction catalysed by mieloperoxidase. The production of $\mathrm{O}_{2}$ and $\mathrm{H}_{2} \mathrm{O}_{2}$ by $\mathrm{O}$. edulis and $C$. gigas was demonstrated (Bachère et al., 1991; Chagot, 1989; Hervio et al., 1989; Nakayama and Maruyama, 1998). Additionally, the nitric oxide synthase occurring in mollusc haemocytes (Conte and Ottaviani, 1995) generates nitric oxide (NO) and eventually peroxinitrite (ONOO $)$, two reactive species inside the group of the reactive nitrogen species (RNS) (Ischiropoulos et al., 1992). NO participates in the elimination of pathogens (Chakravortty and Hensel, 2003; Hahn et al., 2001; James, 1995). In bivalves, NO production is stimulated by phagocytosis (Tafalla et al., 2003) and shows agglutinating (Franchini et al., 1995; Ottaviani et al., 1993) and cytotoxic properties (Romestand and Torreilles, 2002). NO production was reported in haemocytes of various bivalve mollusc species (Arumugam et al., 2000; Gourdon et al., 2001; Nakayama and Mayurama, 1998; Ottaviani et al., 1993; Tafalla et al., 2002, 2003) and preliminary evidence of $\mathrm{ONOO}^{-}$production has been reported in Mytilus galloprovincialis haemocytes (Guerin and Torreilles, 1999) but the NO production in $O$. edulis had never been measured. Some pathogens can modulate the generation of ROS and RNS (Dermine and Desjardins, 1999; Gruenberg and van der 
Goot, 2006; Kwok et al., 2004; Müller, 2004; Schott et al. 2003a, 2003b; Volety and Chu, 1995) in order to survive the host defence mechanisms. ROS levels in O. edulis haemocytes after in vitro phagocytosis of $B$. ostreae were minimal (Cochennec and García, 2000; Hervio, 1992; Morga et al., 2009), which may be due to the block of the respiratory burst by an acid phosphatase activity of the parasite (Hervio et al., 1991). Bonamia ostreae is actively phagocytosed by flat oyster haemocytes (Chagot et al., 1992) but they fail to destroy the parasite, which multiplies within the haemocytes causing haemocyte disruption (Balouet et al., 1983; Pichot et al., 1980). Therefore, a key issue is to determine why oyster haemocytes fail to destroy $B$. ostreae. To improve understanding of the $O$. edulis immune system in relation to bonamiosis, the quantification and comparison of THC, DHC, phagocytosis capacity, and ROS and NO production were carried out between $O$. edulis stocks with different susceptibility to $B$. ostreae, between the susceptible and resistant oyster species $O$. edulis and $C$. gigas., respectively, and between Bonamia-infected and non-infected $O$. edulis.

\section{Materials and methods}

\subsection{Oysters, deploying sites, and sampling dates}

Various O. edulis stocks were used for comparison of haemocytic parameters. Rossmore stock (RO) from Rossmore, Cork Bay (S Ireland), an area exposed to $B$. ostreae since 1980s, included oysters $(75.0 \pm 0.3 \mathrm{~mm}$, mean size \pm S.E.) selected for bonamiosis resistance by using bonamiosis survivors as broodstock through various generations (Culloty et al., 2001, 2004). Tralee stock (TR) included naïve oysters (75.2 $\pm 0.2 \mathrm{~mm}$ ) collected in Tralee Bay (SW Ireland), where bonamiosis has never been detected. Flat oysters from two natural beds of Galicia (NW Spain) were also used, one located in the Ría de Ortigueira (OR) $(72.2 \pm 0.2 \mathrm{~mm}$ ), endemic to bonamiosis (Polanco et al., 1984) and with relative resistance to bonamiosis probably due to natural selection after long term bonamiosis pressure (da Silva et al., 2005), and another located in the Ría de Pontevedra (PO) $(78.2 \pm 0.4 \mathrm{~mm})$ where $B$. ostreae has been detected sporadically with prevalence below $10 \%$ (unpublished results). Additionally, a group of Pacific oysters C. gigas (GI) $(99.8 \pm 0.8 \mathrm{~mm})$, taken from a culture raft in the Ría de Arousa, were included in the comparison.

The oysters were deployed at two sites (Fig. 1) affected by bonamiosis, Ría de Arousa (Galicia, NW Spain) and Rossmore (S Ireland), at different times. In December 2003, a first set of oysters of RO, TR, OR and GI stocks was hung from a raft in the Ría de Arousa. A first sampling to measure haemocytic parameters was performed two months after deployment, on February 2004, a too short period to allow detection of $B$. ostreae infections that could have been acquired in the deployment site (Montes et al., 1991); in fact, no infection was detected in the oysters from this sampling. A second sampling was performed on May 2004, when cases of bonamiosis were expected (da Silva et al., 2005; Montes et al., 1989). On June 2004, a second set of oysters of RO, TR, PO and GI stocks was placed in Ría de Arousa; this set was sampled on April 2005. A third set of oysters of RO, TR and GI stocks was deployed in Rossmore (Cork Bay, Ireland), on November 2004, and sampled on June 2005. The oysters of the samples from Ría de Arousa were kept overnight in tanks with a flow-through seawater delivering system before bleeding them in a laboratory of the Centro de Investigacións Mariñas, whereas oysters of samples from Rossmore were bled on the sampling day, in a laboratory of University College Cork. 


\subsection{Haemolymph collection and $B$. ostreae diagnosis}

The ligament junction between valves was severed carefully to avoid rupture of the adductor muscle. The oyster valves kept slightly opened with a wedge and the pallial cavity was rinsed thoroughly with filtered $(0.22 \mu \mathrm{m})$ seawater to remove debris. Haemolymph was withdrawn from the adductor muscle using a 21 or 23 gauge needle (for $O$. edulis and $C$. gigas respectively) screwed to a $1 \mathrm{~mL}$ cold syringe. Immediately the haemolymph was poured into a cold vial and kept in crushed ice to avoid haemocyte clumping. A drop of haemolymph was examined with light microscopy and blood samples with debris or contamination from other tissues (gonad) were discarded. In the experiments performed in May 2004 and April 2005, a quick diagnosis of $B$. ostreae infections was made after haemolymph collection by examining haemolymph cell monolayers prepared by cytocentrifugation and stained (da Silva and Villalba, 2004). Individual haemolymph samples were classified as B. ostreae-infected or noninfected ones. Haemolymph samples were used individually or pooled depending on the quantity requirements of each parameter. Moreover in all the trials, after bleeding, oyster meat was processed to produce a histological section stained with Harris' hematoxylin and eosin (HHE) (Howard and Smith, 1983), which was examined with light microscope for disease diagnosis. Intensity of infection with $B$. ostreae was estimated according to the following scale (da Silva and Villalba, 2004): null infection (0) when no $B$. ostreae was detected in the section; light infection (1) when $B$. ostreae was observed after thorough searching and then only one to two present in each infected haemocyte, rarely up to 4; moderate infection (2) when $B$. ostreae occurred in various foci of haemocytic infiltration and haemocytes enclosing few (1-4) parasites coexisted with haemocytes bearing up to 10 parasites; and heavy infection (3) when $B$. ostreae was widespread throughout host organs and numerous parasites occurred in each infected haemocyte, even more than 20.

\subsection{Genomic DNA extraction and PCR amplification}

In the June 2005 sampling, the PCR technique was used to diagnose $B$. ostreae infections. A piece of the gills was excised from each oyster. DNA extractions were performed employing the DNAzol reagent ${ }^{\circledR}$ (Invitrogen Life Technologies ${ }^{T M}$ ) according to the manufactures' instructions. The pair of primers BO/ BOAS (Cochennec et al., 2000) was used to amplify a fragment of the Bonamia sp. $18 S$ gene. PCR reactions were performed in a total volume of $25 \mu$ l containing $1 \mu$ l of genomic DNA (20-50 ng), PCR buffer at $1 \times$ concentration, $1.5 \mathrm{mM} \mathrm{MgCl}_{2}, 0.2 \mathrm{mM}$ nucleotides (Roche Applied Science), $0.3 \mu \mathrm{M}$ primers and 0.025 units/ $\mu \mathrm{l}$ Taq DNA polymerase (Roche Applied Science). The cycling protocol was $94^{\circ} \mathrm{C}$ for $2 \mathrm{~min}, 35$ cycles of $94^{\circ} \mathrm{C}$ for $30 \mathrm{sec}, 55^{\circ} \mathrm{C}$ for $45 \mathrm{sec}$ and $72^{\circ} \mathrm{C}$ for $1 \mathrm{~min}$, followed by $72^{\circ} \mathrm{C}$ for $7 \mathrm{~min}$. A negative control (no DNA) was included in all PCR reactions. PCR products were separated on a $2 \%$ agarose (in $1 \times$ Tris-acetic EDTA buffer) gel, stained with ethidium bromide and scanned in a GelDoc XR documentation system (Bio-Rad Laboratories).

\subsection{THC and DHC}

The total haemocyte count was estimated as the number of haemocytes per $\mathrm{mL}$ of haemolymph by examining the haemolymph with a light microscope, using a haemocytometre (Malassez chamber). To estimate the differential haemocyte count, a haemolymph cell monolayer was prepared as described above and examined with a light microscope to allocate 200 haemocytes chosen at random to haemocytic types, namely eosinophilic granulocyte, basophilic granulocyte, refringent granulocyte, large hyalinocyte and small hyalinocyte. However, in the June 2005 samples, because of the 
lack of cytocentrifuge, the DHC was estimated by examining fresh haemolymph and allocating 50-100 haemocytes to granulocyte, large hyalinocyte or small hyalinocyte types.

\subsection{Phagocytic capability of haemocytes}

Six oysters from each group (RO, TR, OR, and GI) from the February 2004 sampling were used to estimate the phagocytic capability. The phagocytosis assay was an adaptation from previous protocols (Bachère et al., 1991). Briefly, an aliquot of haemolymph with $1 \times 10^{5}$ haemocytes was placed on each of 4 slides per oyster. The slides were kept for $1 \mathrm{~h}$ in a dark, humid chamber at $20^{\circ} \mathrm{C}$ to allow haemocyte adhesion onto the slide surface. Next, the serum was carefully drained and $100 \mu \mathrm{L}$ of a suspension of Zymosan A particles (1:10 haemocyte: zymosan ratio) in artificial sea water (sea salts SIGMA in deionised water, $30 \mathrm{ppt}$ ) were added onto two of the slides, whereas $100 \mu \mathrm{L}$ of artificial sea water were added to the other two slides (controls). The slides were incubated for $45 \mathrm{~min}$ in a dark, humid chamber at $20^{\circ} \mathrm{C}$. Then the preparations were washed with artificial sea water, let to dry and finally fixed and stained with Hemacolor kit (Merk). The percentage of cells with phagocytosed particles was estimated in 10 random microscope fields (1000 x), counting at least 200 cells. The number of phagocytosed particles per haemocyte was estimated with a light microscope, in 25 randomly selected haemocytes.

\subsection{Assays for intracellular superoxide production (ICSO)}

In February 2004, the haemolymph of 8 oysters from each group (RO, TR, OR, and GI) was withdrawn; 4 haemolymph pools were produced by pooling the haemolymph of each two oysters. In April 2005, haemolymph cell monolayers were examined to diagnose $B$. ostreae occurrence before pooling haemolymph, thus avoiding the mix of haemolymph from infected and non infected oysters. A total of 11 non infected haemolymph pools from RO, 9 from TR, 10 from PO and 6 from GI were used (2 oysters per pool); additionally, B. ostreae infected haemolymph samples of 2 oysters from RO, 5 from TR and 1 from PO were used individually, because the higher number of cells in the haemolymph of infected oysters allowed using haemolymph from single oysters without pooling. The reduction of nitroblue tetrazolium (NBT) to insoluble blue formazan was used to measure the intracellular production of superoxide anion (ICSO) ( Anderson, 1994; Pipe, 1992). For each sample, haemolymph aliquots $\left(2 \times 10^{5}\right.$ haemocytes) were pipetted into six wells of a 96 microtiter plate. One hundred microliters of $0.01 \mathrm{M}$ phosphate buffer saline (PBS), $\mathrm{pH} 7.4$, containing $2 \% \mathrm{NaCl}$, were added into each well and the microplate was left for $1 \mathrm{~h}$ in a dark, humid chamber at $20^{\circ} \mathrm{C}$ to allow the haemocytes to adhere. Then the microplate was centrifuged (120x g, $10 \mathrm{~min}, 20^{\circ} \mathrm{C}$ ), the supernatant discarded and $150 \mu \mathrm{L}$ NBT solution filtered at $0.22 \mu \mathrm{m}$

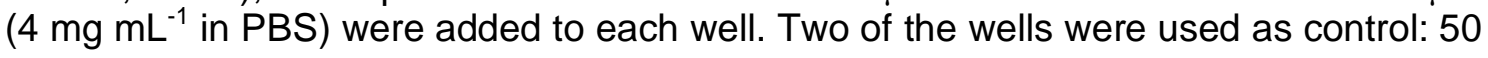
$\mu \mathrm{L}$ of PBS were added in each well. Two different stimuli (2 wells each) for ICSO production were used: (1) $50 \mu \mathrm{L}$ of ZY suspension (1:80 haemocyte:ZY ratio) and (2) $50 \mu \mathrm{L}$ of phorbol 12-myristate 13-acetate (PMA) $\left(20 \mu \mathrm{g} \mathrm{mL}^{-1}\right.$ in PBS) were added per well. Duplicate blank wells, without cells, with NBT, ZY or PMA were prepared. The microplate was incubated for $1 \mathrm{~h}$ in a dark humid chamber at $20^{\circ} \mathrm{C}$. Then the microplate was centrifuged $\left(120 \times \mathrm{g}, 10 \mathrm{~min}, 20^{\circ} \mathrm{C}\right)$, the supernatant removed and the wells were washed twice with $100 \mu \mathrm{L}$ of PBS. After the second PBS-supernatant was removed, haemocytes were fixed with $100 \mu \mathrm{L}$ of $100 \%$ methanol for $10 \mathrm{~min}$ at room temperature. Afterward, the microplate was centrifuged $\left(300 \times \mathrm{g}, 10 \mathrm{~min}, 20^{\circ} \mathrm{C}\right)$, the supernatant removed and the microplate air-dried. Next, the wells were washed five times with $100 \mu \mathrm{L}$ of $50 \%$ methanol, without centrifugation. The reaction product (formazan) was solubilised by adding $120 \mu \mathrm{L} 2 \mathrm{M} \mathrm{KOH}$ plus $140 \mu \mathrm{L}$ DMSO per well, 
mixing until homogenised. The microplate was centrifuged again $\left(1100 \times \mathrm{g}, 5 \mathrm{~min}, 20^{\circ}\right.$ C) and $220 \mu \mathrm{L}$ of supernatant from each well were transferred to a new microplate. The absorbance in each well was read at $620 \mathrm{~nm}$ with a spectrophotometer (Expert 96 microplate reader, ASYS Hitech $\mathrm{GmbH}$, Austria)

\subsection{Assay for extracellular superoxide production (ECSO)}

New aliquots from the same haemolymph samples that had been used for ICSO production were employed to measure extracellular superoxide production (ECSO). The technique is based on the reduction of ferricytochrome $\mathrm{c}$ by the superoxide anion (Adema et al., 1991b). The haemocyte treatment was identical to the ICSO assay until the cells were adhered to the wells and the supernatant was discarded. Then, $100 \mu \mathrm{L}$ of $0.01 \mathrm{M} \mathrm{PBS}$ and $50 \mu \mathrm{L}$ of ferricytochrome $\mathrm{c}$ solution (160 $\mu \mathrm{M}$ in PBS) were added to the wells. Fifty $\mu \mathrm{L}$ of PBS were pipetted into control wells and $50 \mu \mathrm{L}$ of $Z Y$ (80:1, ZY: Haemocyte ratio) as stimulus into the "stimulated" wells. Two replicates were made for each treatment. Duplicate blank wells, without cells, with ferricytochrome C or ZY were prepared. Absorbance was read at $550 \mathrm{~nm}$ immediately and every $10 \mathrm{~min}$ for $50 \mathrm{~min}$ in each well.

\subsection{Assay for hydrogen peroxide production}

In February 2004, 3 haemolymph pools from each oyster group (RO, TR, OR and GI) were produced by grouping the haemolymph of 6 oysters per pool. In April 2005, haemolymph cell monolayers were examined to diagnose $B$. ostreae occurrence before pooling haemolymph; $A$ total of 7 non infected haemolymph pools from RO, 5 from TR, 5 from $\mathrm{PO}$ and 5 from GI were used; additionally, B. ostreae infected haemolymph samples of 1 oyster from RO, 3 from TR and 2 from PO were used individually. The method used to measure the hydrogen peroxide $\left(\mathrm{H}_{2} \mathrm{O}_{2}\right)$ production was based on the $\mathrm{H}_{2} \mathrm{O}_{2}$-mediated, horseradish peroxidase (HRPO) -dependent oxidation of phenolsulfonphthalein (phenol red) (Adema et al., 1991b; Pick and Keisari, 1980; Pipe,

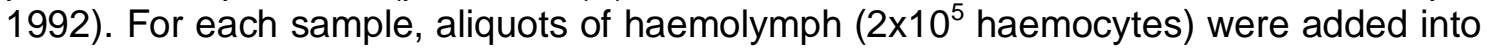
six wells of a 96 well microtiter plate, previously filled with $75 \mu \mathrm{L}$ of PBS per well. The microplate was incubated for $2 \mathrm{~h}$ in a dark and humid chamber at $20^{\circ} \mathrm{C}$, to allow the haemocytes to adhere. In the meantime, solutions of known $\mathrm{H}_{2} \mathrm{O}_{2}$ molarity (range 1- 80 $\mu \mathrm{M}$ ) were prepared to produce a standard curve and a phenol red solution (PRS) was produced (11 mM dextrose, $1.12 \mathrm{mM}$ phenol red in PBS, filtered at $0.22 \mu \mathrm{m}$, kept at $4^{\circ} \mathrm{C}$, and $17 \mathrm{U} \mathrm{mL}^{-1} \mathrm{HRPO}$ were added just before performing the assay). After haemocyte adhesion, the microplate was centrifuged $\left(120 \mathrm{x} \mathrm{g}, 5 \mathrm{~min}, 20^{\circ} \mathrm{C}\right)$. Then 60 $\mu \mathrm{L}$ of each $\mathrm{H}_{2} \mathrm{O}_{2}$ solution for the standard curve were added into free wells by duplicate, the supernatant of the wells with haemocytes was removed and $60 \mu \mathrm{L}$ of PRS added into all the wells. Sixty microliters of PBS were added to control wells (triplicate), whereas the haemocytes of the other three wells were stimulated by adding $60 \mu \mathrm{L}$ of $10 \mu \mathrm{g} \mathrm{mL}{ }^{-1}$ PMA. Triplicate blank wells of PMA and PRS without cells were also prepared. The microplate was incubated for $1 \mathrm{~h}$ in a dark, humid chamber at $20^{\circ} \mathrm{C}$ after which $30 \mu \mathrm{L}$ of $1 \mathrm{M} \mathrm{NaOH}$ were added to stop the reaction. Next, the microplate was centrifuged $\left(1100 \times \mathrm{g}, 5 \mathrm{~min}, 4^{\circ} \mathrm{C}\right)$ and $100 \mu \mathrm{L}$ of the supernatant were transferred into wells of a new microplate in which absorbance at $620 \mathrm{~nm}$ was read. The absorbance was converted to $\mu \mathrm{M} \mathrm{H}_{2} \mathrm{O}_{2}$ using the $\mathrm{H}_{2} \mathrm{O}_{2}$ standard curve and expressed as pmol of $\mathrm{H}_{2} \mathrm{O}_{2}$ formed per $2 \times 10^{5}$ haemocytes.

\subsection{Assay for nitric oxide production}

New aliquots from the same haemolymph samples that had been used for $\mathrm{H}_{2} \mathrm{O}_{2}$ production were employed to measure nitric oxide (NO) production. NO production was 
measured through the quantification of nitrites by the Griess reaction (Novas et al. 2004; Tafalla et al., 2002). Two aliquots of $2 \times 10^{6}$ haemocytes from each sample were added into two vials that were filled with artificial seawater to a final volume of 1 or 1.5 $\mathrm{mL}$. Modified Alsèver's antiaggregant solution (2\%, Bachère et al., 1988) was added to the vials. For each sample, $40 \mu \mathrm{L}$ of artificial seawater were added to one of the vials (control) and the haemocytes of the other vial were stimulated by adding $40 \mu \mathrm{L}$ of PMA (5 $\mu \mathrm{g} \mu \mathrm{L}^{-1}$ in artificial seawater). Then, both vials were kept in the dark for $1 \mathrm{~h}$ at $20^{\circ} \mathrm{C}$. A set of sodium nitrite $\left(\mathrm{NaNO}_{2}\right.$, Panreac) solutions 1-50 $\mu \mathrm{M}$ were prepared to built a standard curve. Next the vials were centrifuged ( $3200 \times$ g, 5 min, RT) and $400 \mu \mathrm{L}$ of the supernatants were transferred into new vials and the nitrates were reduced to nitrites by adding $40 \mu \mathrm{L}$ of nitrate reductase $\left(5 \mathrm{U} \mathrm{mL}^{-1}\right), 3.2 \mu \mathrm{L}$ of $6 \mathrm{mM} \mathrm{NADPH}$ and $10 \mu \mathrm{L}$ of $200 \mu \mathrm{M}$ FAD, and incubating for $20 \mathrm{~min}$. Two aliquots of $150 \mu \mathrm{L}$ from each vial were transferred into wells of a microplate, then $100 \mu \mathrm{L}$ Griess reagent (one part of $1 \%$ sulphanilamide in 5\% phosphoric acid followed by one part of $0.1 \% \mathrm{~N}$-naphthylethylenediamine in deionised water) were added. After 5 min of incubation the absorbance at $550 \mathrm{~nm}$ was read. The NO production was expressed as the $\mathrm{nmol}$ of (nitrites + nitrates) produced by $2 \times 10^{6}$ haemocytes.

\subsection{In vitro encounters B. ostreae- haemocytes analysed by flow cytometry}

In November 2006, four in vitro encounter assays between different proportions of $O$. edulis haemocytes and $B$. ostreae cells and one experiment with $C$. gigas haemocytes were carried out in order to evaluate the influence of $B$. ostreae in the haemocyte respiratory burst. Market size $(>60 \mathrm{~mm})$ oysters that had been cultured in the laboratory of Genetic and Pathology of IFREMER at La Tremblade were used. $B$. ostreae cells were isolated following the procedure of Mialhe et al. (1988) and Cochennec (2001).

In each assay, the haemolymph of 10 oysters was pooled. Three treatments were performed per pool. The haemocyte concentration in all treatments was adjusted at $1 \times 10^{6}$ haemocytes $\mathrm{mL}^{-1}$ with $0.22 \mu \mathrm{m}$ filtered seawater up to a volume of $2 \mathrm{~mL}$. Then, one treatment was used as a control, adding $2 \mathrm{~mL}$ of filtered seawater. The other two treatments involved $B$. ostreae - haemocyte encounters at ratios 5:1 and 10:1 $B$. ostreae: haemocyte, adding $2 \mathrm{~mL}$ of the appropriate $B$. ostreae suspension. In order to measure the respiratory burst, after $2 \mathrm{~h}$ of in vitro encounter, 3 aliquots of $200 \mu \mathrm{L}$ from each treatment were incubated for $30 \mathrm{~min}$ in the dark at room temperature with $2 \mu \mathrm{L}$ of $1 \mathrm{mM}$ dichlorofluorescein diacetate, a non-fluorescent molecule oxidised by ROS to fluorescent diclorofluorescein. Flow cytometric analysis of the respiratory burst was accomplished in an EPICS XL (Beckman-Coulter) flow cytometer, collecting 5000 events for each aliquot. The FL1 detector of the flow cytometer measured the green fluorescent produced by diclorofluorescein and gates were defined on the cytograms to distinguish 3 different categories of haemocytes according to fluorescence intensity: null, medium and high ROS production. Data were analysed with the ExpoXL4 software.

\subsection{Statistical analysis}

One-way analysis of variance (ANOVA), followed by a Tukey's multiple comparison test was used to analyse differences between oyster groups. Three levels of comparisons were performed: (1) non infected O. edulis vs. C. gigas, (2) comparison between flat oyster stocks, just considering non infected oysters, and (3) non infected vs. infected $O$. edulis. To meet the normality assumption of ANOVA, THC dates were $\log _{10}$ transformed and the DHC percentage results were arcsine transformed. When ANOVA requirements were not fulfilled, the non-parametric Kruskal-Wallis test was 
performed followed by the Mann-Whiney test for paired comparisons. In the case of flow cytrometric analyses, the comparisons of haemocyte distribution in different categories of ROS production (null, medium, and high) between treatments (control, $B$. ostreae + haemocytes 5:1, and B. ostreae + haemocytes 10:1) were performed using a contingency table and a $\chi^{2}$ test, in which the categories of ROS production were organised into columns and the treatments into rows; the mean values of the four assays were used to build the contingency table corresponding to $O$. edulis. Significance was concluded at $\mathrm{P} \leq 0.05$. The statistical analyses were performed using Minitab 15 software.

\section{Results}

\subsection{Histological observations}

No B. ostreae infection was detected in the February 2004 sampling. In May 2004, B. ostreae prevalence was $5 \%$ in RO, $7 \%$ in TR and $5 \%$ in OR and mean infection intensity values were 2.3, 1.3 and 2.7, respectively. In April 2005, B. ostreae pre valence was $17 \%$ in RO, 31\% in TR and $24 \%$ in PO oysters, with mean infection intensity values of $1.58,1.68$ and 2.00 , respectively. In the June 2005 sampling, the prevalence was $64 \%$ in RO and $34 \%$ in TR, with mean infection intensity values of 1.4 and 1.8, respectively. Additionally, in the May 2004 sampling, heavy haemocytic infiltration and necrosis signs were observed in $67 \%$ and $30 \%$, respectively, of RO oysters, $59 \%$ and $5 \%$, respectively, of TR oysters, and $27 \%$ and $9 \%$, respectively, of OR oysters. No remarkable lesion was observed in Crassotrea gigas.

\subsection{Total haemocyte count (THC)}

The THC of $C$. gigas was significantly lower than that of all the O. edulis stocks in every sampling date. Moreover, the THC in $C$. gigas showed a narrow range of values $(2.6 \pm$ 0.3 to $3.5 \pm 0.4 \times 10^{6}$ haemocytes $\mathrm{mL}^{-1}$ ) (Fig. 2), whereas $O$. edulis stocks showed marked variability in THC between sampling dates. With regard to the comparison among $O$. edulis stocks, the THC of RO was significantly lower than that of TR in February 2004 (Fig. 2A); on the contrary, the THC of RO was significantly higher than that of TR in May 2004 (Fig. 2B) and no significant difference was found between $O$. edulis stocks in June 2005 (Fig. 2C). In May 2004, a marked increase of the THC values was found in all $O$. edulis stocks. This observation was associated, with tissue haemocyte infiltrations and necrosis in gills and visceral mass in $B$. ostreae non infected oysters. Furthermore, the THC values of the $B$. ostreae infected oysters were significantly higher than those of the non-infected ones in May 2004 (Fig 2B), whereas no significant differences were found either between $B$. ostreae infected and non infected oysters in June 2005 (Fig. 2C).

\subsection{Differential haemocyte count (DHC)}

Six haemocyte types were sorted according to the observations of the haemolymph cell monolayers. Hyalinocytes appeared as large cells (ca. $30 \mu \mathrm{m}$ ) lacking granules. Granulocytes, with similar size as hyalinocytes, had cytoplasmic granules and were classified in eosinophilic, basophilic and refringent, according to the staining characteristics of their granules. Finally, small basophilic granulocytes (ca. $7 \mu \mathrm{m}$ ) and small hyalinocytes $(10-15 \mu \mathrm{m})$ were distinguished. 
The hyalinocyte was the most abundant haemocyte type in all the oyster groups when the DHC was based on stained haemolymph cell monolayers (February 2004, May 2004, April 2005 and June 2005), but this type was the least abundant when the DHC was based on the examination of fresh haemolymph (June 2005). The comparisons between oyster groups in DHC are summarised in Fig 3 and Table 1. C. gigas showed significantly higher percentages of basophilic granulocytes and total granulocytes than O. edulis on February 2004 and May 2004. However the difference in the percentage of granulocytes was not significant between both oyster species in June 2005, when the estimation was based on the examination of fresh haemolymph. O. edulis showed significantly higher percentages of hyalinocytes and small hyalinocytes than $C$. gigas on May 2004 and June 2005 but the differences were not significant on February 2004. The comparisons between $O$. edulis stocks did not show significant differences between the Irish stocks (RO and TR) except for hyalinocytes and small hyalinocytes on May 2004. Some significant differences were detected between the Galician (OR and PO) and the Irish stocks, although for the case of OR, the only significant difference occurring in the 2 sampling events (February 2004 and May 2004) in which it was involved corresponded to a significantly lower percentage of eosinophilic granulocytes than in TR. In the case of PO oysters, they showed higher percentages of eosinophilic granulocytes and total granulocytes and lower percentage of small hyalinocytes than RO oysters in the only sampling event in which the former were involved (April 2005).

The comparisons between $B$. ostreae infected and non infected $O$. edulis did not show any significant difference on May 2004. The infected oysters showed a higher percentage of basophilic granulocytes and small basophilic granulocytes and a lower percentage of refringent granulocytes on April 2005. On June 2005, the infected oysters showed a lower percentage of granulocytes and higher percentage of small hyalinocytes.

\subsection{Phagocytic capability of haemocytes}

No significant differences were detected in the phagocytic activity between all the oyster groups. The mean percentages ( \pm S.E.) of phagocytosing haemocytes were 33 $\pm 4 \%, 31 \pm 6 \%, 32 \pm 3 \%$, and $34 \pm 3 \%$ for RO, TR, OR and GI, respectively. The same trend was found in the phagocytic index in all the cases; the mean number of zymosan particles per haemocyte was $4.2 \pm 0.5,4.1 \pm 0.4,3.7 \pm 0.3$, and $4.0 \pm 0.2$ for RO, TR, $\mathrm{OR}$ and $\mathrm{GI}$, respectively.

\subsection{Assay for intracellular superoxide production (ICSO)}

The ICSO values corresponding to non-stimulated haemocytes (control) and haemocytes stimulated with either zymosan or PMA, both in February 2004 and April 2005, are shown in Fig.4. In most cases the highest ICSO production was recorded in zymosan stimulated haemocytes. No significant differences in ICSO production either between $O$. edulis and $C$. gigas or between $O$. edulis stocks were found in any experiment. $O$. edulis infected by $B$. ostreae were only detected in the April 2005 assays and the ICSO tended to be lower in $B$. ostreae infected than in non infected $O$. edulis groups, both in stimulated and non stimulated haemocytes (Fig. 4B), although differences were not statistically significant. 


\subsection{Assay for extracellular superoxide production (ECSO)}

In February 2004, the greatest ECSO was obtained after 30 min of stimulation with zymosan in all the flat oyster stocks, whereas the maximum in C. gigas was reached at 50 min (Fig. 5A). Nevertheless no significant difference between O. edulis and C. gigas values were detected at each recording time. Significant differences between oyster stocks were only detected at time zero, when ECSO production of stimulated haemocytes in RO was significantly lower than in TR.

In April 2005, the highest ECSO production was obtained after 10 or 20 min of stimulation with zymosan in all the oyster groups (Fig. 5B). There were not significant differences between $O$. edulis and $C$. gigas or between $O$. edulis stocks. The ECSO production was lower in the controls of $B$. ostreae infected oysters than in the controls of non infected ones. The addition of zymosan enhanced the ECSO production in the $B$. ostreae non infected oysters, but in the $B$. ostreae infected oysters it did not because the ECSO production was higher (RO) in controls or similar (TR) with regard to the zymosan-stimulated haemocytes (Fig. 5).

\subsection{Assay for hydrogen peroxide $\left(\mathrm{H}_{2} \mathrm{O}_{2}\right)$ production}

In February 2004, no significant differences were found in the $\mathrm{H}_{2} \mathrm{O}_{2}$ production between oyster groups, either in controls or in haemocytes incubated with PMA (Fig. 6A). PMA failed to stimulate $\mathrm{H}_{2} \mathrm{O}_{2}$ production except in TR oysters.

In April 2005, $\mathrm{H}_{2} \mathrm{O}_{2}$ production in the controls of $C$. gigas was significantly higher than in the $\mathrm{O}$. edulis controls (Fig. 6B). Differences in $\mathrm{H}_{2} \mathrm{O}_{2}$ production in the controls between $O$. edulis stocks and between $B$. ostreae infected and non infected $O$. edulis were not significant. The effect of $\mathrm{PMA}$ on $\mathrm{H}_{2} \mathrm{O}_{2}$ production by haemocytes was highly variable because it enhanced the production in $O$. edulis groups, except in the $B$. ostreae infected oysters from $\mathrm{RO}$ and $\mathrm{PO}$, and it did not in $C$. gigas. Differences in the net production of $\mathrm{H}_{2} \mathrm{O}_{2}$ due to addition of PMA between $C$. gigas and $O$. edulis were significant. Within $\mathrm{O}$. edulis stocks, the lowest $\mathrm{H}_{2} \mathrm{O}_{2}$ production in PMA stimulated haemocytes was found in RO and differences between RO and $\mathrm{PO}$ were significant. However, differences between $B$. ostreae infected and non infected $O$. edulis were not significant.

\subsection{Assay for nitric oxide (NO) production}

In February 2004 (Fig. 7A), NO production was enhanced by PMA stimulation except in $C$. gigas, thus the net NO production due to PMA addition in $C$. gigas was significantly lower than in the O. edulis. Differences in NO production in the controls between $O$. edulis stocks and between $B$. ostreae infected and non infected $O$. edulis were not significant, either in controls or in PMA-stimulated cells. In April 2005 (Fig. 7B), no significant differences between oyster groups were found, either in controls or in PMAstimulated cells.

\subsection{In vitro encounters B. ostreae- haemocytes analysed by flow cytometry}

The respiratory burst in $O$. edulis and $C$. gigas haemocytes measured by flow cytometry showed three haemocyte subpopulations with null, medium and high ROS production (Fig. 8). In the case of $O$. edulis, the production of ROS by haemocytes was significantly associated with the addition of $B$. ostreae because the differences in the distribution of haemocytes into categories of ROS production between the 3 treatments (control, B. ostreae:haemocytes 5:1, and B. ostreae:haemocytes 10:1) were significant: the number of haemocytes without ROS production was higher in haemocytes incubated with $B$. ostreae with regard to the control and the number of haemocytes with medium and high ROS production was lower in haemocytes incubated with $B$. ostreae than in the control. However, the differences between the two treatments in which $B$. 
ostreae was added (5:1 and 10:1) to $O$. edulis haemocytes were not significant. In the case of $C$. gigas, the production of ROS by haemocytes was independent from treatments.

\section{Discussion}

The comparative study of cellular defence mechanisms between oyster groups with different susceptibility to bonamiosis showed some significant differences between $C$. gigas and $O$. edulis and between $B$. ostreae infected and non infected $O$. edulis but no consistent differences between $O$. edulis stocks. Examination of histological sections showed differences in $B$. ostreae prevalence and mean infection intensity between oyster groups but those differences are not further discussed because the experimental design is not appropriate to do it. Isolate scarce sampling to estimate prevalence and infection intensity and the lack of information on mortality rates prevent from having solid conclusions on differences in susceptibility between $O$. edulis stocks through this study. For example heavy $B$. ostreae infections could have caused death of oysters in some $O$. edulis stocks before sampling thus resulting in a decrease of the prevalence and the mean infection intensity recorded at sampling.

The total haemocyte count was significantly lower in $C$. gigas than in $O$. edulis. Additionally, the total haemocyte count range of $C$. gigas was narrower than $O$. edulis. This trend for both species was previously reported (Bachère et al., 1991; Chagot, 1989) and even in Perkinsus marinus experimental infections of $C$. gigas the total haemocyte count kept steady (La Peyre et al., 1995). Moreover, mechanically stressed C. gigas (Lacoste et al., 2002) showed a rise of THC that reached levels comparable to the highest values measured under natural conditions in this study. In the February 2004 experiment, the mean values of THC in all the O. edulis stocks were consistent with previous reports (Chagot, 1989; Cochennec-Laureau et al., 2003), whereas the values recorded three months later, in May 2004, were extremely high, especially in the Irish stocks. A seasonal variation in THC for flat oyster has been described (da Silva et al., 2008), but the records of May 2004 were unusual. The examination of histological sections of the $B$. ostreae non infected flat oysters of the May 2004 experiment showed necrosis and heavy haemocyte infiltration of tissues but the causative agent for the abnormal THC values was not detected. A lack of adaptation to environmental conditions of the Irish stocks could have contributed to the abnormally high THC. $B$. ostreae infected $O$. edulis showed significantly higher THC than non infected flat oysters in the May 2004 experiment; however, differences between infected and non infected flat oysters were not significant in June 2005. One possible explanation could be that diagnosis of $B$. ostreae infection in the June 2005 experiment was performed by $\mathrm{PCR}$, which is a more sensitive technique than microscopy examination (Balseiro et al., 2006): Thus, PCR could have detected early stages of infection without a significant effect on THC, which would be undetected with microscopy. Da Silva et al. (2008) reported that the strongest effect of $B$. ostreae infections on THC was reached with moderate and heavy infections. Total haemocyte count is a sensitive parameter in relation to a number of infections in bivalve molluscs, such as Crassostrea virginica infected by Perkinsus marinus (Anderson, 1995; Chu and La Peyre, 1993) and by Haplosporidium nelsoni (Ford et al., 1993), and Ruditapes philippinarum infected by Vibrio tapetis (Allam and Ford, 2006; Oubella et al., 1993).

Four types of granulocyte and two types of hyalinocyte haemocytes were identified in this study. This classification, according with the affinity to specific dyes and sizes, is an extension of previous haemocyte classifications (Chagot, 1989; Xue et al., 2000), since a high heterogeneity in the enzymatic content of different stained granules of granulocytes has been demonstrated in some bivalves (Aladaileh et al., 2007; Huffman and Tripp, 1982; Pipe et al., 1993). The DHC was highly dependent on the 
technique, that is to say if its estimation was based on the examination of either fixed and stained haemolymph cell monolayers produced by cytocentrifugation or fresh haemolymph. The hyalinocyte was reported as the most abundant haemocyte type in the haemolymph of $O$. edulis in some previous studies (Bachère et al., 1991; Cochennec-Laureau et al., 2003; Xue et al., 2000). However, Chagot (1989) found small hyalinocyte as the most abundant haemocyte type, whereas da Silva et al. (2008) reported the granulocyte as the most abundant one. Marked differences in DHC were found between $C$. gigas and $O$. edulis. This fact deserves further research to determine its significance on the resistance to $B$. ostreae and other diseases. The comparisons of $\mathrm{DHC}$ between $O$. edulis stocks showed some isolated differences but there were not consistent through the study. With regard to association of $B$. ostreae infection with $\mathrm{DHC}$, the results were different depending on the sampling time and place; those of June 2005 in Cork agreed with previous reports of a significant increase of the proportion of small hyalinocytes and decrease of that of granulocytes in $B$. ostreae infected O. edulis (Chagot, 1989; da Silva et al., 2008). That could suggest that DHC of oysters influences the susceptibility to disease or that disease provokes changes in DHC (or both): on the one hand, if granulocytes were more efficient to destroy $B$. ostreae (Cochennec-Laureau et al., 2003), perhaps oysters with a higher proportion of granulocytes could face more efficiently the infection; on the other hand, considering the small hyalinocyte as a blast cell (Aladaileh et al., 2007; Chang et al., 2005; Cima et al., 2000; Hine, 1999; Xue et al., 2000), an increase of its proportion associated with $B$. ostreae infection could be interpreted as an increase of haemopoietic activity to face the parasite.

No significant difference in the ability to phagocytose zymosan between either oyster species or flat oyster stocks was detected. That could suggest that the differences in susceptibility to. $B$. ostreae infection between oyster species and between flat oyster stocks should not be due to distinct phagocytic ability. Similar phagocytic activity values between $C$. gigas and $O$. edulis haemocytes challenged with $B$. ostreae had been reported (Chagot et al., 1992; Mourton et al., 1992), although greater adhesion of $B$. ostreae cells to $C$. gigas haemocytes had been found (Fisher, 1988). In contrast, a greater uptake of live Perkinsus marinus by Crassotrea virginica haemocytes with regard to $C$. gigas suggested a certain level of specificity in the recognition/endocytosis of the parasite by its natural host species (Gauthier and Vasta, 2002; Goedken et al., 2005; La Peyre et al., 1995). A case of mollusc-parasite interaction in which the susceptibility is associated with differences in phagocytic ability of host haemocytes corresponds to the snail Biomphalaria glabrata and the trematode Schistosoma mansoni, since differences in the ability to phagocytose yeast between haemocytes from resistant and susceptible strains of the snail were recorded after previous contact with the trematode (Fryer and Bayne, 1996). The influence of $B$. ostreae infection on the haemocyte phagocytic ability was not tested in this study. Morga et al. (2009) did not detect a significant difference in the ability to phagocytose fluorescent beads between haemocytes previously in vitro exposed to $B$. ostreae and those non exposed, whereas Morga et al. (2011a) found significant differences only when the previous in vitro exposure to $B$. ostreae lasted $2 \mathrm{~h}$ but not when it lasted 1,4 and $8 \mathrm{~h}$.

The assays regarding respiratory burst showed marked differences in some comparisons. The production of both ICSO and ECSO was reduced in non stimulated and stimulated haemocytes from $B$. ostreae infected $O$. edulis with regard to non infected ones, which was consistent with the reduction of ROS production recorded through flow cytometry in $O$. edulis haemocytes due to in vitro challenge with $B$. ostreae. Differences in production of either ICSO or ECSO in non stimulated and stimulated haemocytes between $O$. edulis and $C$. gigas were not significant. However, the in vitro challenge of $C$. gigas haemocytes with $B$. ostreae did not involve reduction of ROS production. The interference of $B$. ostreae in the respiratory burst would help the parasite to survive and divide within $O$. edulis haemocytes as previously reported (Hervio, 1992; Hervio et al., 1989; Morga et al., 2009, 2011a) and the lack of 
interference in the case of $C$. gigas haemocytes would contribute to explain the resistance of the Pacific oyster to bonamiosis. The lack of consistency of the differences in production of either ICSO or ECSO in non stimulated and stimulated haemocytes between $O$. edulis stocks suggests that superoxide production should not be responsible for the differences in susceptibility to $B$. ostreae between those $O$. edulis stocks.

The comparisons of $\mathrm{H}_{2} \mathrm{O}_{2}$ production did not show significant differences between oyster groups, except for the case $O$. edulis vs. C. gigas. PMA was chosen as stimulant because our previous assays had shown higher stimulation for haemocyte $\mathrm{H}_{2} \mathrm{O}_{2}$ production with PMA than with zymosan (unpublished results). However, PMA did not enhance $\mathrm{H}_{2} \mathrm{O}_{2}$ production in many cases of this study, especially for $C$. gigas. A similar trend had been reported by Lambert et al. (2003). If the higher $\mathrm{H}_{2} \mathrm{O}_{2}$ production in $C$. gigas non stimulated haemocytes than in $O$. edulis could contribute to destroy $B$. ostreae, thus explaining differences in susceptibility between both oyster species, is not clear and could be further studied.

Our results suggest that the nitric oxide does not contribute to explain differences in susceptibility to bonamiosis between oyster groups. The estimation of nitric oxide production with the Griess reagent does not allow measuring the production of other reactive nitrogen species (Arumugam et al., 2000), in particular peroxynitrite, the most cytotoxic (Pacher et al., 2007). The role of peroxynitrite in destruction of $B$. ostreae and its contribution to differences in susceptibility to this parasite between oyster groups remains unclear.

In conclusion, significant differences in THC, DHC and respiratory burst between $O$. edulis and $C$. gigas were detected, which could be linked to differences in susceptibility to bonamiosis between both species. Very light $B$. ostreae infection has been rarely detected in C. gigas (Lynch et al., 2010) and haemocytes of $C$. gigas are able to phagocytose B. ostreae (Chagot et al., 1992; Mourton et al., 1992); however, the molecular and physiological keys of $C$. gigas resistance to $B$. ostreae remain unknown, it could be not a product of hemocyte activities and other factors could play a more significant role. Additionally, significant changes in THC, DHC and respiratory burst of $O$. edulis associated with $B$. ostreae infection were found. However no haemocyte parameter of this study seemed to be linked to the differences in susceptibility to bonamiosis between the $O$. edulis stocks involved in the study. Likely, other factors are responsible for those differences. The role of a number of lysosomal enzymes, anti protease activity in the host serum and levels of expression of heat shock proteins in the host haemolymph has been analysed and the results are being processed for publication. Recent genomic (Morga et al., 2011b; Gómez-Martín et al., 2012) and proteomic (Cao et al. 2010) approaches could help to disclose genes and biochemical processes responsible for bonamiosis resistance. Availability of molecular diagnostic tools allowed to detect $B$. ostreae in early stages of oyster development (Lynch et al. 2005; Arzul et al., 2011) but infection uses to reach clinical levels in adult oysters. Whether the infection progresses or remain at subclinical level could depend on the ability of the oyster to handle stress; factors affecting that turning point are unknown. This is a point that needs further research.

\section{Acknowledgments}

Authors thank Sarah Culloty for allowing the use of her laboratory facilities at University College Cork for analyses in June 2005. The company Jose Maria Daporta Leiro e Hijos, S.L., the Confraría de Pescadores Nosa Señora do Carmen de Cariño, and David Hugh-Jones and Tristan Hugh Jones (Atlantic Shellfish Ltd.) helped with field 
work and supplied oysters. Elena Penas, María Isabel Meléndez, María Victoria Gregorio, Carlota Rodríguez, and María Varela provided field and laboratory technical assistance. This work was supported by funds from the UE 5th Framework Programme - Craft, through the project Q5CR-2002-72338. P.C. was supported by a scholarship from the Consellería de Pesca, Marisqueo e Acuicultura da Xunta de Galicia.

\section{References}

Adema, C,M., van der Knaap, W.P.W., Sminia, T., 1991a. Molluscan hemocytemediated cytotoxicity: the role of reactive oxygen intermediates. Rev. Aquat. Sci. 4, 201-223.

Adema, C.M., van Deutekom-Mulder, E.C., van der Knaap, W.P.W., Meuleman, E.A., Sminia, T., 1991b. Generation of oxygen radicals in hemocytes of the snail Lymnaea stagnalis in relation to the rate of phagocytosis. Dev. Comp. Immunol.15, 17-26.

Aladaileh, S., Nair, S.V., Birch, D., Raftos, D.A., 2007. Sydney rock oyster (Saccostrea glomerata) hemocytes: morphology and function. J. Invertebr. Pathol. 96, 48-63.

Allam, B., Ford, S.E., 2006. Effects of the pathogenic Vibrio tapetis on defence factors of susceptible and non-susceptible bivalves species: I. Haemocytes changes following in vitro challenge. Fish Shellfish Immunol. 20, 374-383.

Allam, B., Ashton-Alcox, K.A., Ford, S.E., 2001. Haemocyte parameters associated with resistance to brown ring disease in Ruditapes spp. clams. Dev. Comp. Immunol. 25, 365-375.

Anderson, R.S., 1994. Hemocyte-derived reactive oxygen intermediate production in four bivalve mollusks. Dev. Comp. Immunol. 18, 89-96.

Anderson, R.S., Burreson, E,M,, Paynter. K.T., 1995, Defense responses of hemocytes withdrawn from Crassostrea virginica infected with Perkinsus marinus. J. Invertebr. Pathol. 66, 82-89.

Arumugam, M., Romestand. B., Torreilles, J., 2000, Nitrite released in haemocytes from Mytilus galloprovincialis, Crassostrea gigas and Ruditapes decussatus upon stimulation with phorbol myrstate acetate. Aquat. Living Resour. 13, 173-177.

Arzul, I., Langlade, A., Chollet, B., Robert, M., Ferrand, S., Omnes, E., Lerond, S., Couraleau, Y., Joly, J.P., François, C., Garcia, C. 2011. Can the protozoan parasite Bonamia ostreae infect larvae of flat oysters Ostrea edulis? Vet. Parasitol. 179, 69-76

Auffret, M., 1989. Comparative study of the hemocytes of two oyster species: the European flat oyster, Ostrea edulis, Linnaeus, 1750 and the pacific oyster, Crassostrea gigas (Thunberg, 1793). J. Shellfish Res.8, 367-373.

Babior, B.M., 1997. Superoxide: a two-edged sword. Bra. J. Med. Biol. Res. 30, 14155.

Bachère, E., Chagot, D., Grizel, H.. 1988. Cell separation by centrifugal elutriation. Am. Fish. Soc. Spec. Publ. 18, 281-285.

Bachère, E., Hervio, D., Mialhe, E., 1991. Luminol-dependent chemiluminescence by hemocytes of two marine bivalves, Ostrea edulis and Crassostrea gigas. Dis. Aquat. Org. 11, 173-180.

Bachère, E., Mialhe, E., Noel, D., Boulo, V., Morvan, A., Rodríguez, J., 1995. Knowledge and research prospects in marine mollusc and crustacean immunology. Aquaculture 132, 17-32.

Badwey, J.A., Karnovsky, M.L., 1980. Active oxygen species and the functions of phagocytic leukocytes. Ann Rev Biochem 49, 695-726.

Balouet, G., Poder, M., Cahour, A., 1983. Haemocytic parasitosis: morphology and pathology of lesions in the French flat oyster, Ostrea edulis L. Aquaculture 34, 1-14.

Balseiro, P., Fernández Conchas, R., Montes, J., Gómez-León, J., Novoa, B., Figueras, A., 2006. Comparison of diagnosis techniques for the protozoan parasite Bonamia ostreae in flat oyster Ostrea edulis. Aquaculture 261, 1135-1143. 
Chagot, D.J., 1989. Caracterisation morphologique et functionelle des hemocytes d'Ostrea edulis et de Crassostrea gigas, mollusques bivalves. Etude in vitro de leurs interactions avec le protozoaire Bonamia ostreae (Ascetospora). Thèse du diplome de l'Ecole Pratique des Hautes Etudes, Université de Montpellier, France.

Chagot, D., Boulo, V., Hervio, D., Mialhe, E., Bachère, E., Mourton, C., Grizel, H., 1992. Interactions between Bonamia ostreae Protozoa: (Ascetospora) and hemocytes of Ostrea edulis and Crassostrea gigas (Mollusca: Bivalvia): entry mechanisms. J. Invertebr. Pathol. 59, 241-249

Chakravortty, D., Hensel, M., 2003. Inducible nitric oxide synthase and control of intracellular bacterial pathogens. Microbes Infect. 5, 621-627.

Chang, S.-J., Tseng, S.-M., Chou, H.-Y., 2005. Morphological caracterization via light and electron microscopy of the hemocytes of two cultured bivalves: a comparison study between the hard clam (Meretrix lusoria) and Pacific oyster (Crassostrea gigas). Zool. Sci. 44, 144-152.

Cheng, T.C., 1981. Bivalves, in: Ratcliffe, N.A., Rowley, A.F. (Eds.), Invertebrate blood cells. Academic Press, London, UK, pp. 233-300.

Cheng, T.C., 1996. Hemocytes: forms and functions, in: Kennedy, V.S., Newell, R.I.E., Eble, A.F. (Eds.), The Eastern oyster. Maryland Sea Grant. College Park, MD, USA, pp. 299-333.

Cheng, T.C., 2000. Cellular defense mechanisms in oysters, in: Fingerman, M., Nagabhushanam, R. (Eds.), Recent advances in marine biotechnology. Science Publishers, Enfield, NH, USA, pp. 43-83

Chu, F.-L.E., 2000. Defense mechanisms of marine bivalves, in: Fingerman, M., Nagabhushanam, R. (Eds.), Recent advances in marine biotechnology. Science Publishers, Enfield, NH, USA, p 1-42

Chu, F.-L.E., La Peyre, J.F., 1993. Perkinsus marinus susceptibility and defenserelated activities in eastern oysters Crassostrea virginica: temperature effects. Dis. Aquat. Org. 16, 223-234.

Cima, F., Matozzo, V., Marin, M.G., Ballarin, L., 2000. Haemocytes of the clam Tapes philippinarum (Adams \& Reeve, 1850): morphofunctional characterisation. Fish. Shellfish Immunol. 10, 677-693.

Cochennec, N., 2001. Bonamia ostreae, parasite de l'huître plate,Ostrea edulis, sa position taxonomique parmi les parasites du groupe "Microcell," analyses des interactions hôte/parasite chez plusieurs populations d'huîtres plates. Thèse de Doctorat, Université de la Rochelle, France.

Cochennec, N., Garcia, S., 2000. Flow cytometric comparison of esterase and radicals oxygen intermediate productions by Ostrea edulis haemocytes uninfected and infected by the protistan parasite Bonamia ostreae. J. Eukaryot. Microbiol. 48, 16A-17A.

Cochennec, N., Renault, T., Chollet, B., Maffart, P., 1995. Comparison of haemograms from resistant and susceptible European flat oysters, Ostrea edulis, exposed to the parasite Bonamia ostreae, in: Abstracts book of the 7th International Conference "Disease of Fish and Shellfish", Eur. Assoc. Fish Pathologists, Palma de Mallorca, Spain, 10-15 Sept 1995, p.17.

Cochennec, N., le Roux F., Berthe, F., Gerard, A., 2000. Detection of Bonamia ostreae based on small subunit ribosomal probe. J. Invertebr. Pathol. 76, 26-32.

Cochennec-Laureau, N., Auffret, M., Renault, T., Langlade, A., 2003. Changes in circulating and tissue-infiltrating hemocyte parameters of European flat oysters, Ostrea edulis, naturally infected with Bonamia ostreae. J. Invertebr. Pathol. 83, 23-30.

Conte, A., Ottaviani, E., 1995. Nitric oxide synthase activity in molluscan hemocytes. FEBS Lett. 365, 120-124.

Culloty, S.C., Novoa, B., Pernas, M., Longshaw, M., Mulcahy, M.F., Feist, S.W., Figueras, A. 1999. Susceptibility of a number of bivalve species to the protozoan parasite Bonamia ostreae and their ability to act as vectors for this parasite. Dis, Aquat, Org. 37, 73-80 
Culloty, S.C., Cronin, M.A., Mulcahy, M.F., 2001. An investigation into the relative resistance of Irish flat oysters Ostrea edulis L. to the parasite Bonamia ostreae (Pichot et al., 1980). Aquaculture 2001 199, 229-244.

Culloty, S.C., Cronin, M.A., Mulcahy, M.F., 2004. Potential resistance of a number of populations of the oyster Ostrea edulis to the parasite Bonamia ostreae. Aquaculture;237, 41-58.

da Silva, P.M, Villalba, A., 2004. Comparison of light microscopic techniques for the diagnosis of the infection of the European flat oyster Ostrea edulis by the protozoan Bonamia ostreae. J. Invertebr. Pathol. 85, 97-104.

da Silva, P.M., Fuentes, J., Villalba, A., 2005. Growth, mortality and disease susceptibility of oyster Ostrea edulis families obtained from brood stocks of different geographical origins, through on growing in the Ría de Arousa (Galicia, NW Spain). Mar. Biol. 147, 965-977.

da Silva, P.M., Comesaña, P., Fuentes, J., Villalba, A., 2008. Variability of haemocyte and haemolymph parameters in European flat oyster Ostrea edulis families obtained from brood stocks of different geographical origins and relation with infection by the protozoan Bonamia ostreae. Fish Shellfish Immunol. 24, 551-563.

Dermine, J.-F., Desjardins, M., 1999. Survival of intracellular pathogens within macrophages. Protoplasma 210, 11-24

Elston, R.A., Kent, M.L., Wilkinson, M.T., 1987. Resistance of Ostrea edulis to Bonamia ostreae infection. Aquaculture 64, 237-242.

Faisal, M., MacIntyre, E.A., Adham, K.G., Tall, B.D., Kothary, M.H., La Peyre, J.F., 1998. Evidence for the presence of protease inhibitors in eastern (Crassostrea virginica) and Pacific (Crassostrea gigas) oyster. Comp. Biochem. Physiol. B 121, 161168.

Feng, S.Y., 1998. Cellular defense mechanisms of oysters and mussels. Am. Fish. Soc. Spec. Publ. 18, 153-168.

Fisher, W.S., 1988. In vitro binding of parasites Bonamia ostreae and latex particles by hemocytes of susceptible and insusceptible oysters. Dev. Comp. Immunol. 12, 43-53.

Ford, S.E., Kanaley, S.A., Littlewood, D.T.J., 1993. Cellular responses of oysters infected with Haplosporidium nelsoni: changes in circulating and tissue-infiltrating hemocytes. J. Invertebr. Pathol. 61, 49-57.

Franchini, A., Fontanili, P., Ottaviani, E., 1995. Invertebrate immunocytes: relationship between phagocytosis and nitric oxide production. Comp. Biochem. Physiol. B 110, 403-407.

Fryer, S.E., Bayne, C.J., 1996. Host-parasite interactions in molluscs, in: Rinkevich, B., Müller, W.E.G. (Eds.), Invertebrate immunology. Springer Verlag, Heidelberg:,Germany, pp. 131-153.

Gauthier, J.D., Vasta, G.R., 2002. Effects of plasma from bivalve mollusk species on the in vitro proliferation of the protistan parasite Perkinsus marinus. J. Exp. Zool. 292, 221-230.

Goedken, M., Morsey, B., Sunila, I., de Guise, S., 2005. Immunomodulation of Crassostrea gigas and Crassostrea virginica cellular defense mechanisms by Perkinsus marinus. J. Shellfish Res. 24, 487-496.

Gourdon, I., Guerin, M.-C., Torreilles, J., Roch, P., 2001. Nitric oxide generation by hemocytes of the mussel Mytilus galloporvincialis. Biol. Chem. 5, 1-6.

Gruenberg, J., van der Goot, F.G., 2006. Toxoplasma: guess who's coming to dinner. Cell 125, 226-228.

Guerin, M.-C., Torreilles, J., 1999. Production of peroxynitrite by zymosan stimulation of Mytilus galloprovincialis haemocytes in vitro. Fish Shellfish Immunol.;9, 509-518.

Hahn, U.K., Bender, R.C., Bayne, C.J.,2001. Involvement of nitric oxide in killing of Schistosoma mansoni sporocysts by hemocytes from resistant Biomphalaria glabrata.

J. Parasitol. 87, 778-785. 
Hervio, D., 1992. Contribution a l'etude de Bonamia ostreae (Ascetospora), protozoaire parasite de l'huitre Ostrea edulis (Bivalvia), et a l'analyse des interactions hoteparasite. Ph D Thesis, Blaise Pascal University, Clermont Ferrand, France.

Hervio, D., Bachère, E., Mialhe, E., Grizel, H., 1989. Chemiluminescent responses of Ostrea edulis and Crassostrea gigas hemocytes to Bonamia ostreae (Ascetospora). Dev. Comp. Immunol. 13, 449.

Hervio, D., Chagot, D., Grizel, H., Mialhe, E., Goldin, P., 1991. Localization and characterization of acid phosphatase activity in Bonamia ostreae (Ascetospora), an intrahemocytic protozoan parasite of the flat oyster Ostrea edulis (Bivalvia). Dis. Aquat. Org. 12, 67-70.

Hervio, D., Bachère, E., Boulo, V., Cochennec, N., Vuillemin, V., Le Coguic, Y., Cailletaux, G., Mazurie, J., Mialhe, E., 1995. Establishment of an experimental infection protocol for the flat oyster, Ostrea edulis, with the intrahaemocytic protozoan parasite, Bonamia ostrae: application in the selection of parasite-resistant oysters. Aquaculture 132, 183-194.

Hine, P.M., 1999. The inter-relations of bivalve haemocytes. Fish Shellfish Immunol. 9, 367-85.

Howard, D.W., Smith, C.S., 1983. Histological techniques for bivalve mollusks. NOAA technical memorandum NMFS-F/NEC-25. Woods Hole, MA, USA.

Huffman, J.E., Tripp, M.R., 1982. Cell-Types and hydrolytic enzymes of soft shell clam (Mya arenaria) Hemocytes. J. Invertebr. Pathol. 40, 68-74.

Ischiropoulos, H., Zhu, L., Beckman, J.S., 1992. Peroxynitrite formation from macrophage-derived nitric oxide. Arch. Biochem. Biophys. 298, 446-451.

James, S.L., 1995. Role of nitric oxide in parasitic infections. Microbiol. Rev. 59, 533547.

Kimura, H., Sawada, T., Oshima, S., Kozawa, K., Ishioka, T., Kato, M., 2005. Toxicity and roles of reactive oxygen species. Current drug targets- Inflamm. Allergy 4, 489495.

Kwok, L.Y., Schlüter, D., Clayton, C., Soldati, D., 2004. Erratum in: Mol Microbiol. 2005 58, 915. Ding, Martina added. The antioxidant systems in Toxoplasma gondii and the role of cytosolic catalase in defence against oxidative injury. Mol. Microbiol. 51, 47-61. Lacoste, A., Malham, S.K., Gelebart, F., Cueff, A., Poulet, S.A., 2002. Stress-induced immune changes in the oyster Crassostrea gigas. Dev. Comp. Immunol. 26, 1-9.

Lambert, C., Soudant, P., Choquet, G., Paillard, C., 2003. Measurement of Crassostrea gigas hemocyte oxidative metabolism by flow cytometry and the inhibiting capacity of pathogenic vibrios. Fish Shellfish Immunol. 15, 225-240.

La Peyre, J.F., Chu, F.-L.E., Vogelbein, W.K., 1995. In vitro interaction of Perkinsus marinus merozoites with eastern and Pacific oyster hemocytes. Dev. Comp. Immunol. 19, 291-304.

Lynch, S.A., Armitage, D.V., Wylde, S., Mulcahy, M.F., Culloty, S.C. 2005. The susceptibility of young prespawning oysters, Ostrea edulis, to Bonamia ostreae. J. Shellfish Res. 24, 1019-1025.

Lynch, S.A., Abollo, E., Ramilo, A., Cao, A., Culloty, S.C., Villalba, A. 2010. Observations raise the question if the Pacific oyster, Crassostrea gigas, can act as either a carrier or a reservoir for Bonamia ostreae or Bonamia exitiosa. Parasitology 137, 1515-1526.

Mialhe, E., Bachère, E., Chagot, D., Grizel, H., 1988. Isolation and purification of the protozoan Bonamia ostreae (Pichot et al. 1980), a parasite affecting the flat oyster Ostrea edulis. Aquaculture 71, 293-299.

Mitta, G., Vandenbulcke, F., Roch, P., 2000. Original involvement of antimicrobial peptides in mussel innate immunity. FEBS Lett. 486, 185-190.

Montes, J., 1991. Lag time for infestation of flat oyster (Ostrea edulis L.) by Bonamia ostrae in estuaries of Galicia. Aquaculture 93, 235-239. 
Montes, J., Acosta, C.P., Guerra, A., 1989. Oyster mortality in Galicia (NW Spain), in: De Pauw, N., Jaspers, E., Ackefors, H., Wilkins, N. (Eds.), Aquaculture a biotechnology in progress. European Aquaculture Society, Bredene, Belgium, pp. 941-948.

Morga, B., Arzul, I., Chollet, B., Renault, T., 2009. Infection with the protozoan parasite Bonamia ostreae modifies in vitro haemocyte activities of flat oyster Ostrea edulis. Fish Shellfish Immunol. 26, 836-842.

Morga, B., Renault, T., Faury, N., Chollet, B., Arzul, I., 2011a. Cellular and molecular responses of haemocytes from Ostrea edulis during in vitro infection by the parasite Bonamia ostreae. Int. J. Parasitol. 41, 755-764.

Morga, B., Renault, T., Faury, N., Chollet, B., Arzul I. 2011b. Cellular and molecular responses of haemocytes from Ostrea edulis during in vitro infection by the parasite Bonamia ostreae. Int J. Parasitol. 41, 755-764

Mourton, C., Boulo, V., Chagot, D., Hervio, D., Bachère, E., Mialhe, E., Grizel, H., 1992. Interactions between Bonamia ostreae (Protozoa: Ascetospora) and Hemocytes of Ostrea edulis and Crassostrea gigas (Mollusca: Bivalvia): in Vitro Sistem Establishment. J. Invertebr. Pathol. 59, 235-240.

Müller, S., 2004. Redox and antioxidant systems of the malaria parasite Plasmodium falciparum. Mol. Microbiol. 53, 1291-1305.

Naciri-Graven, Y., Martin, A.G., Baud, J.-P., Renault, T., Gerard, A., 1998. Selecting the flat oyster Ostrea edulis (L.) for survival when infected with the parasite Bonamia ostreae. J. Exp. Mar. Biol. Ecol. 224, 91-107.

Naciri-Graven, Y., Haure, J., Gerard, A., Baud, J.-P., 1999. Comparative growth of Bonamia ostreae resistant and wild flat oyster Ostrea edulis in an intensive system II. Second year of the experiment. Aquaculture 171, 195-208.

Nakayama, K., Maruyama, T., 1998. Differential production of active oxygen species in photo-symbiotic and non symbiotic bivalves. Dev. Comp. Immunol. 22, 151-159.

Novas, A., Cao, A., Barcia, R., Ramos-Martinez, J.I., 2004. Nitric oxide release by hemocytes of the mussel Mytilus galloprovincialis Lmk was provoked by interleukin-2 but not by lipopolysaccharide. Int. J. Biochem. Cell. B 36, 390-394.

Ottaviani, E., Paemen, L.R., Cadet, P., Stefano, G.B. 1993. Evidence for nitric oxide production and utilization as a bacteriocidal agent by invertebrate immunocytes. Eur. J. Pharm. Environ. 248, 319-324.

Oubella, R., Maes, P., Paillard, C., Auffret, M., 1993. Experimentally-induced variation in hemocyte density for Ruditapes philippinarum and $R$. decussatus (Mollusca, Bivalvia). Dis. Aquat. Organ. 15, 193-197.

Oubella, R., Maes, P., Allam, B., Paillard, C., Auffret, M., 1996. Selective induction of hemocytic response in Ruditapes philippinarum (Bivalvia) by different species of Vibrio (Bacteria). Aquat. Living Resourc. 9, 137-143.

Pacher, P., Beckman, J.S. Liaudet, L., 2007. Nitric oxide and peroxynitrite in health and disease. Physiol. Rev. 87, 315-424.

Parry, H.E., Pipe, R.K. 2004. Interactive effects of temperature and copper on immunocompetence and disease susceptibility in mussels (Mytilus edulis). Aquat. Toxicol. 69, 311-325.

Pichot. Y,, Comps, M., Tigé, G., Grizel, H., Rabouin, M.-A., 1980. Recherches sur Bonamia ostreae gen. n., sp. n., parasite nouveau de I'huitre plate Ostrea edulis L. Rev Trav Inst Pęches Marit 43, 131-40.

Pick, E., Keisari, Y., 1980. A simple colorimetric method for the measurement of hydrogen peroxide produced by cells in culture. J. Immunol. Methods 38, 161-170.

Pipe, R.K., 1992. Generation of reactive oxygen metabolites by the haemocytes of the mussel Mytilus edulis. Dev. Comp. Immunol. 16, 111-122.

Pipe, R.K., Porte, C., Livingstone, D.R., 1993. Antioxidant enzymes associated with the blood cells and haemolymph of the mussel Mytilus edulis. Fish Shellfish Immunol. 3, 221-233. 
Polanco, E., Montes, J., Outon, M.J., Melendez, M.I., 1984. Situation pathologique du stock d'huitres plaes en Galice (Espagne) en relation avec Bonamia ostreae. Haliotis 14, 91-5.

Reeves, E.P., Nagl, M., Godovac-Zimmermann, J., Segal, A.W., 2003. Reassessment of the microbicidal activity of reactive oxygen species and hypochlorous acid with reference to the phagocytic vacuole of the neutrophil granulocyte. J. Med. Microbiol. $52,643-651$.

Reid, H.I., Soudant, P., Lambert, C., Paillard, C., Birkbeck, T.H., 2003. Salinity effects on immune parameters of Ruditapes philippinarum challenged with Vibrio tapetis. Dis. Aquat. Org. 56, 249-258.

Renault, T., Cochennec, N., Grizel, H., 1995. Bonamia ostreae, parasite of the European flat oyster, Ostrea edulis, does not experimentally infect the Japanese oyster, Crassostrea gigas. Bull. Eur. Ass, Fish Pathol, 15, 78-80.

Renault, T., Xue, Q., Chilmonczyk, S., 2001. Flow cytometric analysis of European flat oyster, Ostrea edulis, haemocytes using a monoclonal antibody specific for granulocytes. Fish Shellfish Immun 11, 269-274.

Romestand, B., Torreilles, J., 2002. Etude de la resiteance de I'huitre Crassostrea gigas face a la protozoose a Perkinsus marinus. Haliotis 31,21-32.

Roos, D., van Bruggen, R., Meischl, C., 2003. Oxidative killing of microbes by neutrophils. Microbes infect. 5, 1307-1315.

Schott, E.J., Robledo, J.-A., Wright, A.C., Silva, A.M., Vasta, G.R. 2003a. Gene organization and homology modeling of two iron superoxide dismutases of the early branching protist Perkinsus marinus. Gene 309, 1-9.

Schott, E.J., Pecher, W.T., Okafor, F., Vasta, G.R., 2003b. The protistan parasite Perkinsus marinus is resistant to selected reactive oxygen species. Exp. Parasitol. 105, 232-240.

Tafalla, C., Novoa, B., Figueras, A., 2002. Production of nitric oxide by mussel (Mytilus galloprovincialis) hemocytes and effect of exogenous nitric oxide on phagocytic functions. Comp. Biochem. Physiol. B 132, 423-431.

Tafalla, C., Gomez- León, J., Novoa, B., Figueras, A., 2003. Nitric oxide production by carpet shell clam (Ruditapes decussatus) hemocytes. Dev. Comp. Immunol. 27, 197205.

Volety, A.K., Chu, F.L.E., 1995. Suppression of chemiluminescence of eastern oyster (Crassostrea virginica) hemocytes by the protozoan parasite Perkinsus marinus. Dev. Comp. Immunol. 19, 135-142.

Xue, Q., Renault, T., Cochennec, N., Gerard, A., 2000. Separation of European flat oyster, Ostrea edulis, haemocytes by density gradient centrifugation and SDS-PAGE characterisation of separated haemocyte sub-populations. Fish Shellfish Immunol. 10, 155-165. 


\section{Tables}

Table 1. Significance of comparisons of the relative abundance of haemocyte types between oyster groups. Ostrea edulis stocks: OR, Ortigueira; PO, Pontevedra; RO, Rossmore, TR, Tralee. Significance levels: NS, non significant; ${ }^{*}, 0.05 \geq \mathrm{P}>0.01 ;{ }^{* *}, 0.01 \geq \mathrm{P}>0.001 ;{ }^{* * *}, \mathrm{P} \leq 0.001$.

\begin{tabular}{|c|c|c|c|}
\hline & $\begin{array}{c}\text { February } \\
2004\end{array}$ & $\begin{array}{l}\text { May } \\
2004\end{array}$ & April 2005 \\
\hline \multicolumn{4}{|c|}{ Eosinophilic granulocytes } \\
\hline O. edulis vs. C. gigas & $\star \star \star$ & NS & - \\
\hline O. edulis stocks & $\begin{array}{c}\text { RO (a) } \\
\text { b) } \\
\text { TR (a) } \\
\text { OR (b) }\end{array}$ & $\begin{array}{l}\text { RO (a, } \\
\text { b) } \\
\text { TR (a) } \\
\text { OR (b) }\end{array}$ & $\begin{array}{c}\text { RO }(a) \\
\text { TR }(a, b) \\
\text { PO (b) }\end{array}$ \\
\hline
\end{tabular}

infected

Basophilic granulocytes

O. edulis vs. C. gigas

O. edulis stocks

*** *** -

NS

b)

$\operatorname{TR}(\mathrm{a})$

OR (b)

O. edulis infected vs. non NS

O. edulis infected vs. non

\section{Granulocytes}

O. edulis vs. C. gigas

NS

$O$. edulis stocks

NS infected

Small basophilic

granulocytes
O. edulis vs. C. gigas
O. edulis stocks

$\begin{array}{llc}\star \star * & - & - \\ \operatorname{RO}(a, & - & \text { NS } \\ \text { b) } & & \\ \operatorname{TR}(a) & & \\ \text { OR (b) } & & \\ - & - & \end{array}$

O. edulis infected vs. non infected

\section{Hyalinocytes}

O. edulis vs. C. gigas

O. edulis stocks infected

\section{Small hyalinocytes}

O. edulis vs. C. gigas

$O$. edulis stocks

O. edulis infected vs. non infected

\section{Refringent granulocytes}

O. edulis vs. C. gigas

O. edulis stocks

$\begin{array}{ccc}\text { NS } & \star & - \\ \text { RO (a) } & \text { NS } & \text { NS } \\ \text { TR (a,b) } & & \\ \text { OR (b) } & & \\ - & \text { NS } & * \star \star\end{array}$

O. edulis infected vs. non infected

\section{Total granulocytes}

O. edulis vs. C. gigas

O. edulis stocks

**

NS

NS

$\mathrm{RO}(\mathrm{a})$

$\operatorname{TR}(a, b)$

PO (b)

O. edulis infected vs. non

NS

NS infected

\section{Hyalinocytes}

O. edulis vs. C. gigas

O. edulis stocks

$\begin{array}{lcc}\text { NS } & \star \star \star & - \\ \text { NS } & \text { RO (a) } & \text { NS } \\ & \text { TR (b) } & \\ & \text { OR (a, }\end{array}$

$O$. edulis infected vs. non infected 
b)

O. edulis infected vs. non $\quad-\quad$ NS

NS

infected

Small hyalinocytes

O. edulis vs. C. gigas

NS $\quad * * *$

O. edulis stocks

$\mathrm{RO}(\mathrm{a}) \quad \mathrm{RO}(\mathrm{a}) \quad \mathrm{RO}(\mathrm{a})$

$\operatorname{TR}(a) \quad \operatorname{TR}(b) \quad \operatorname{TR}(a, b)$

OR (b) OR (a) PO (b)

$O$. edulis infected vs. non - NS NS

infected 


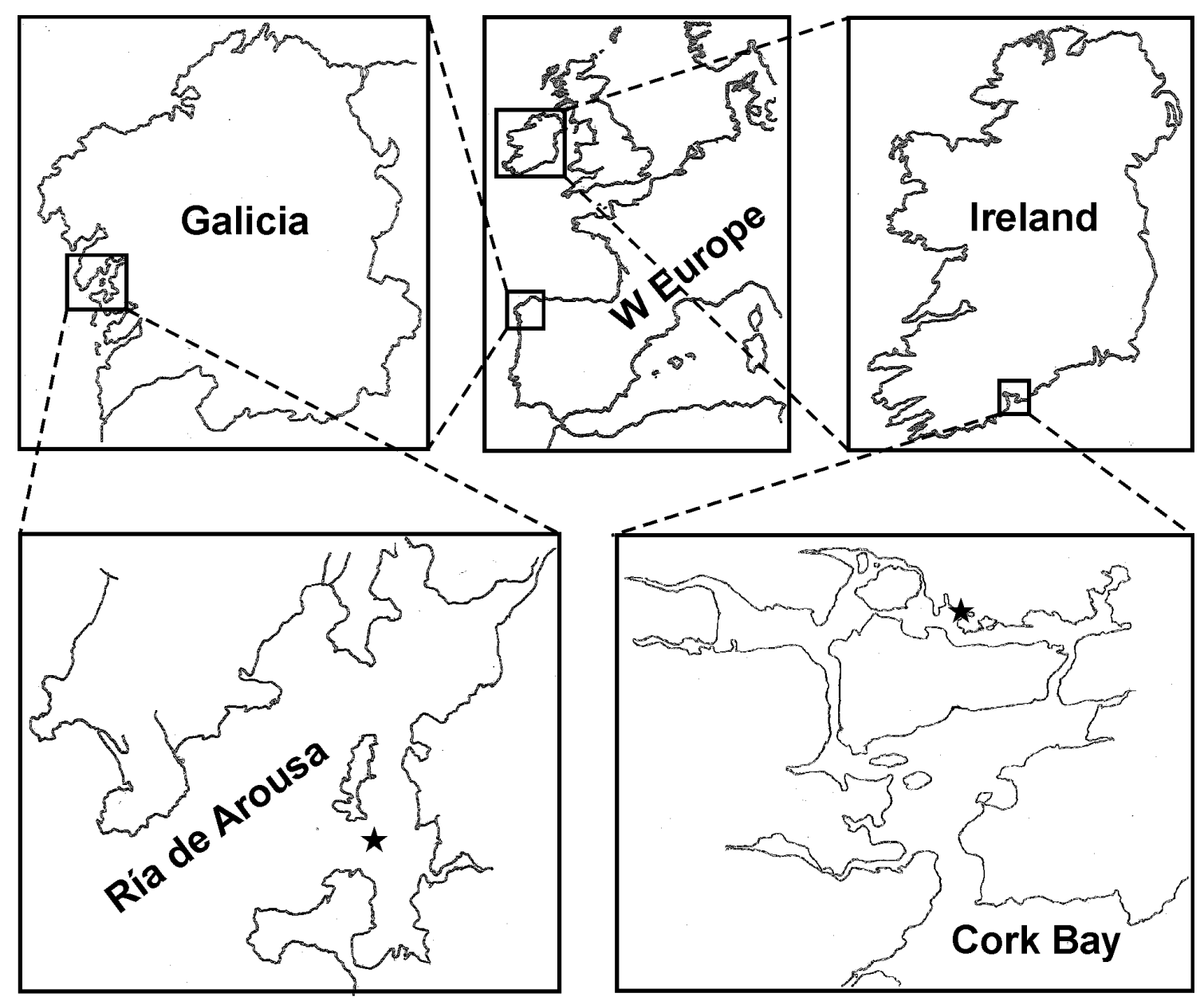

Fig. 1

Fig. 1. Maps showing the deployment location $\left(^{*}\right)$ of the oyster batches in Cork Bay (Ireland) and Ría de Arousa (Galicia, Spain). 


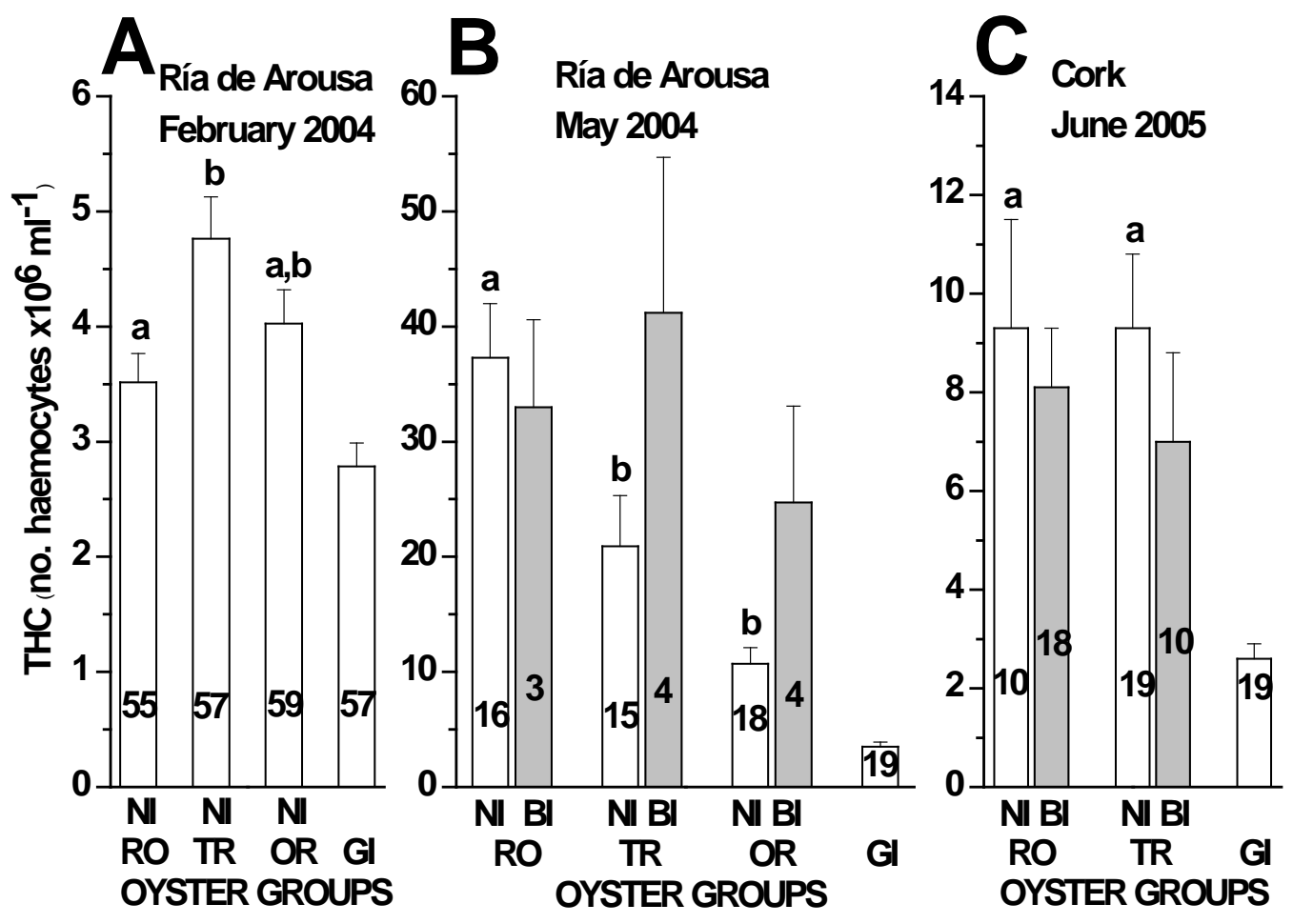

Fig.2

Fig. 2. Total haemocyte count (mean \pm S.E.) of the different oyster groups in February (A) and May (B) 2004 and in June 2005 (C). BI: Bonamia ostreae infected oysters; NI: $B$. ostreae non infected oysters. Different letters above the bars represent significant differences between $O$. edulis stocks (just considering non infected oysters). The number of examined oysters is shown within each bar. 

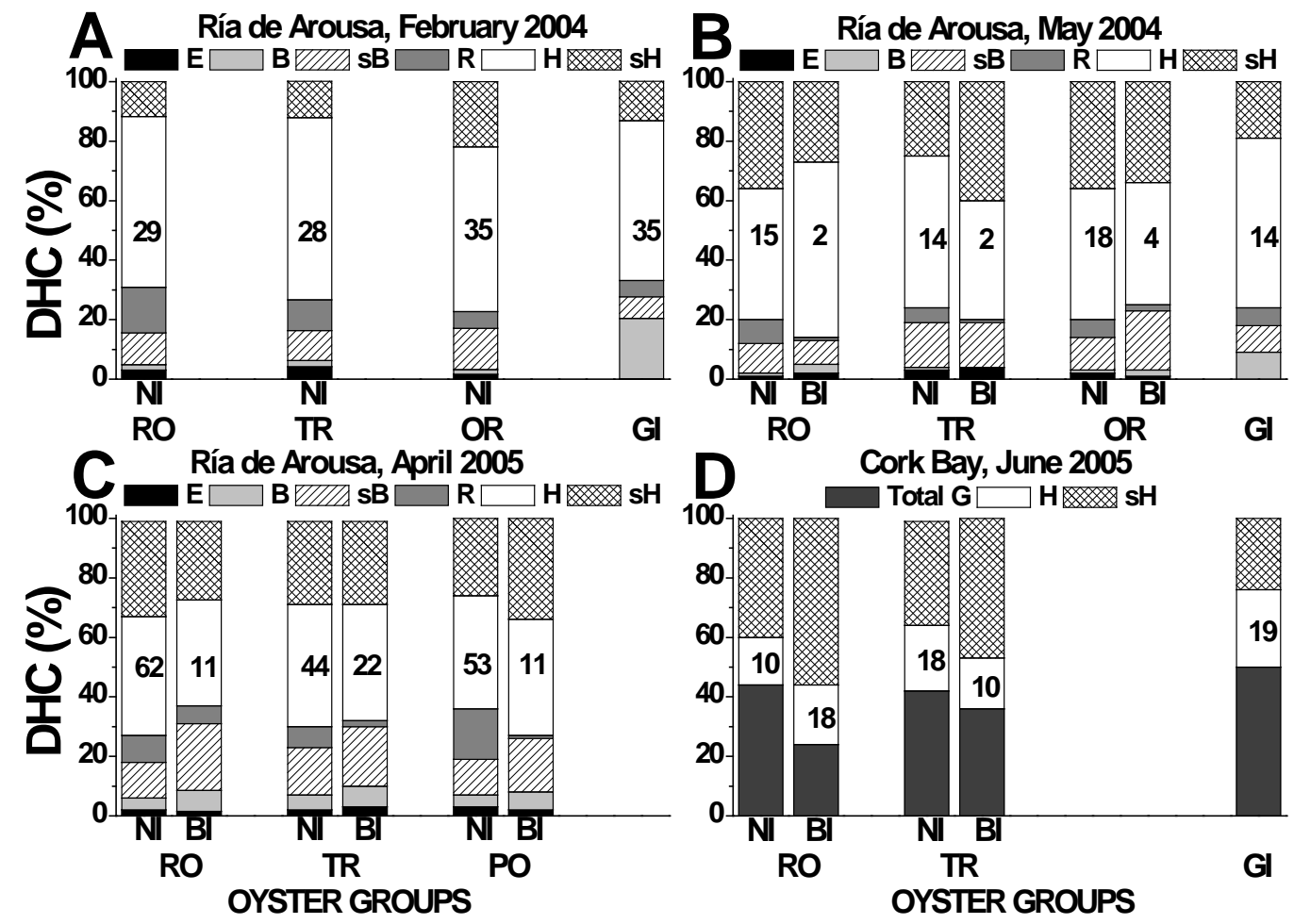

Fig.3

Fig. 3. Differential haemocyte count (mean percentage of each haemocyte type) of the different oyster groups in February (A) and May (B) 2004 and in April (C) and June (D) 2005. Haemocyte types: E, eosinophilic granulocytes; B, basophilic granulocytes; sB, small basophilic granulocytes; $\mathrm{R}$, refringent granulocytes; $\mathrm{H}$, hyalinocytes, $\mathrm{sH}$, small hyalinocytes. Oyster groups:. GI, Crassostrea gigas; OR, Ortigueira, RO, Rossmore; TR, Tralee; BI, Bonamia ostreae infected Ostrea edulis; NI, non infected Ostrea edulis. The number of examined oysters is shown within each bar. 

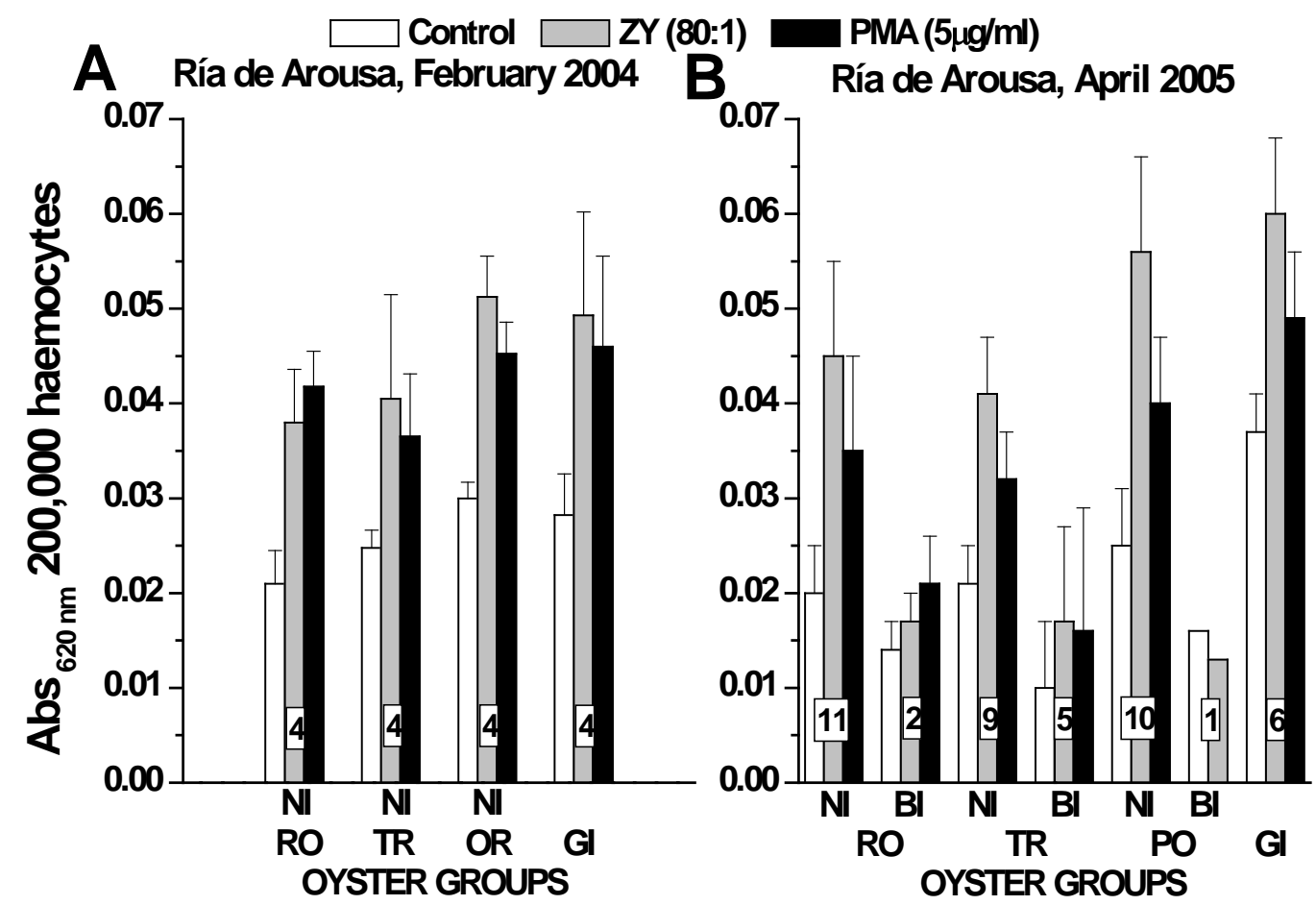

Fig.4

Fig. 4. Intracellular superoxide anion (ICSO) production in haemocytes of the different oyster groups in February 2004 (A) and April 2005 (B). Bar height represents mean ( \pm $\mathrm{S}: \mathrm{E}$.) absorbance derived from Nitro Blue Tetrazolium reduction in non stimulated (control), Zymosan (Zy) and PMA stimulated haemocytes. Oyster groups:. GI, Crassostrea gigas; OR, Ortigueira, PO, Pontevedra; RO, Rossmore; TR, Tralee; BI, Bonamia ostreae infected Ostrea edulis; NI, non infected Ostrea edulis. The number of examined haemolymph pools from each oyster group is shown on the bars. 


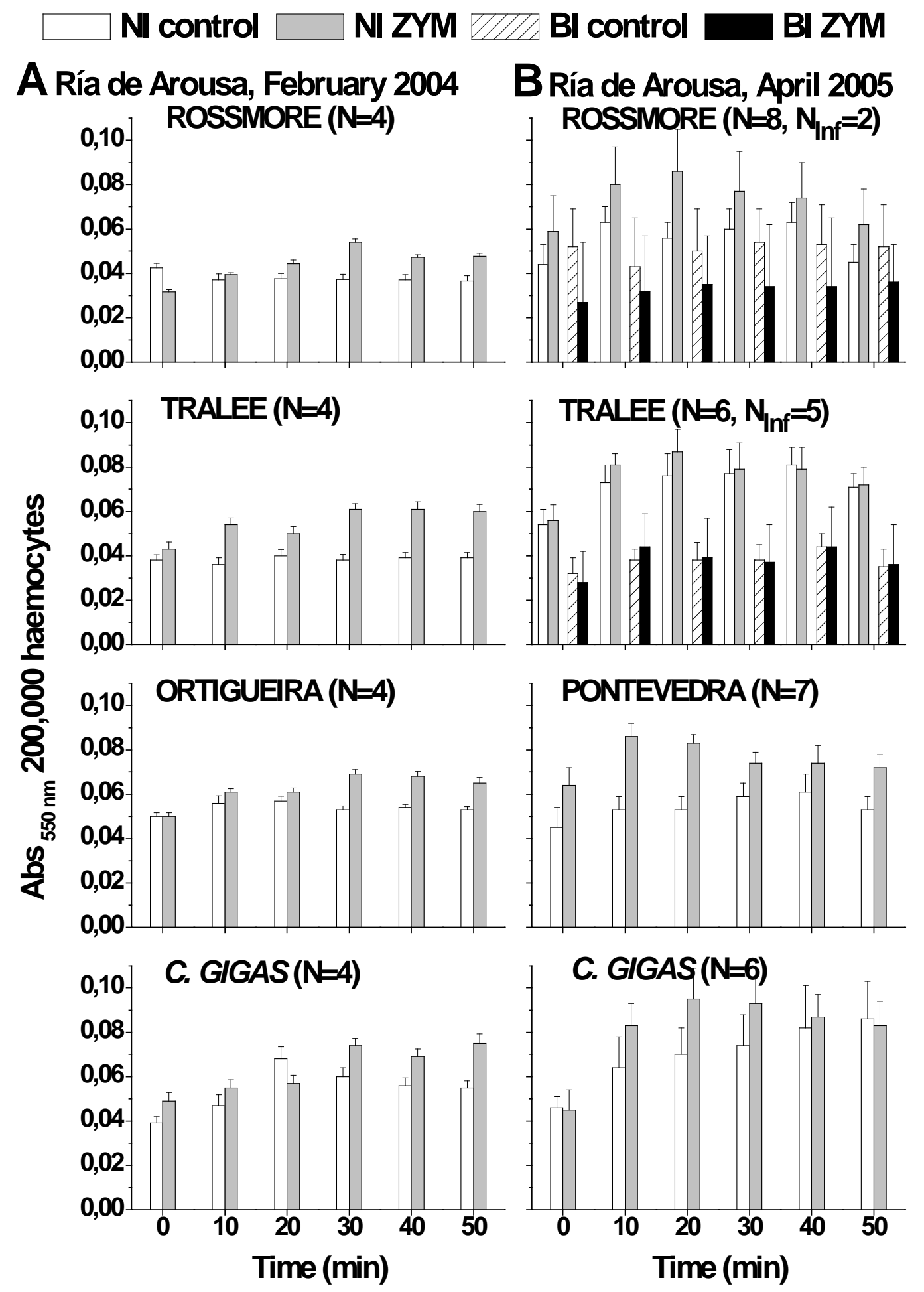

Fig. 5. Extracellular superoxide anion (ECSO) production in haemocytes of the different oyster groups, recorded at 10 min periods, in February 2004 (A) and April 2005 (B). Bar height represents mean ( \pm S.E.) absorbance derived from ferricytochrome $C$ reduction in non stimulated (control) and Zymosan (ZYM) stimulated haemocytes. NI, oyster subsets in which $B$. ostreae infection was not detected; BI: oyster subsets affected by bonamiosis. $\mathrm{N}$ and $\mathrm{N}_{\mathrm{inf}}$ are the number of examined haemolymph pools derived from $B$. ostreae non infected and infected oysters, respectively. 


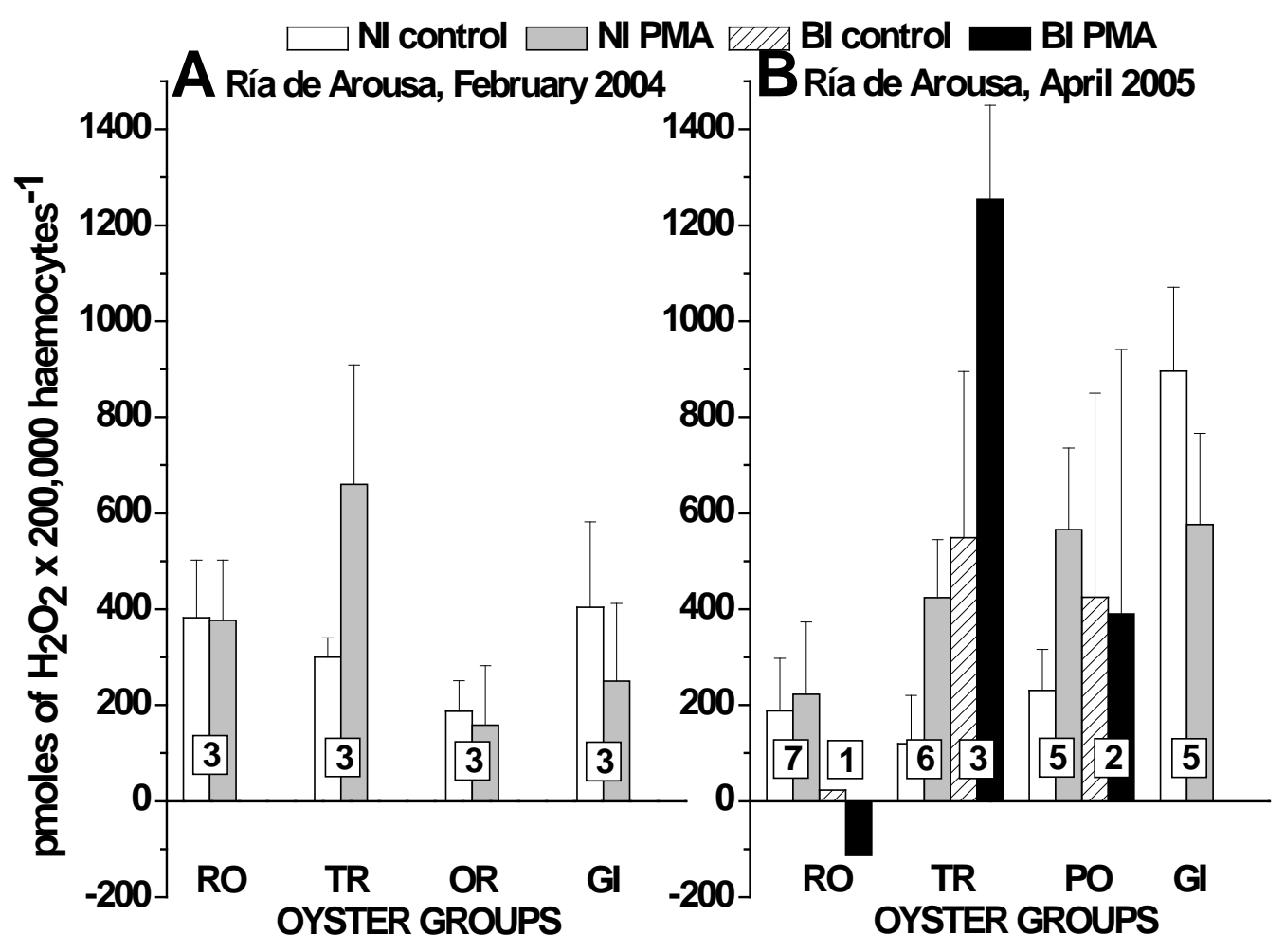

Fig.6

Fig. 6. Hydrogen peroxide production by haemocyte of the different oyster groups in February 2004 (A) and April 2005 (B). Bar height represents the mean ( \pm S.E.) concentration of $\mathrm{H}_{2} \mathrm{O}_{2}$ in non stimulated (control) and PMA stimulated haemocytes. Oyster groups:. GI, Crassostrea gigas; OR, Ortigueira, PO, Pontevedra; RO, Rossmore; TR, Tralee; BI, Bonamia ostreae infected Ostrea edulis; NI, non infected Ostrea edulis. The number of examined haemolymph pools from each oyster group is shown on the bars. 


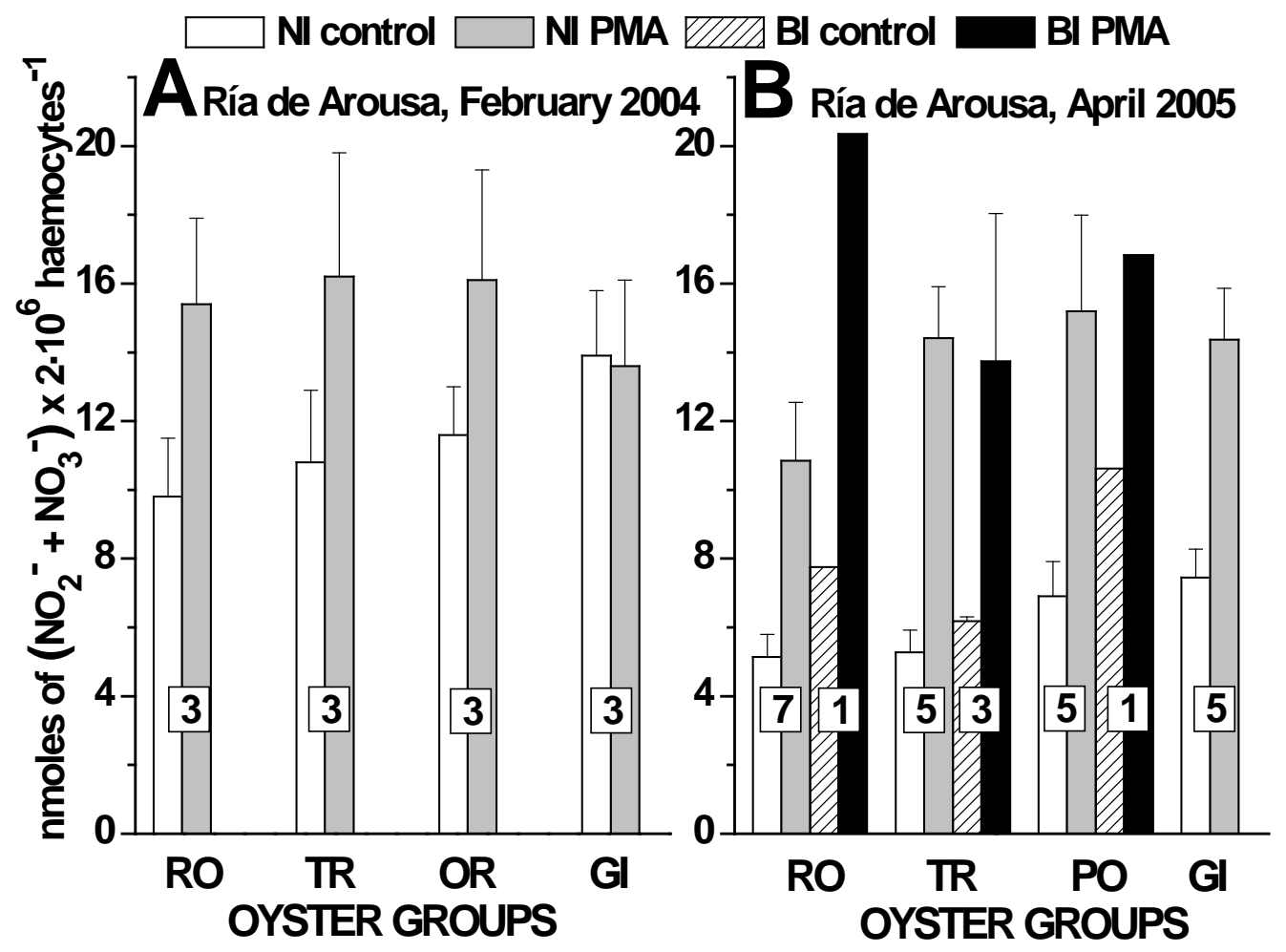

Fig.7

Fig. 7. Production of nitric oxide, expressed as concentration of nitrites plus nitrates, in haemocytes of the different oyster groups in February 2004 (A) and April 2005 (B). Bar height represents mean ( \pm S.E.) concentration of nitrites plus nitrates in non stimulated (control) and PMA stimulated haemocytes. Oyster groups:. GI, Crassostrea gigas; OR, Ortigueira, PO, Pontevedra; RO, Rossmore; TR, Tralee; BI, Bonamia ostreae infected Ostrea edulis; NI, non infected Ostrea edulis. The number of examined haemolymph pools from each oyster group is shown on the bars. 


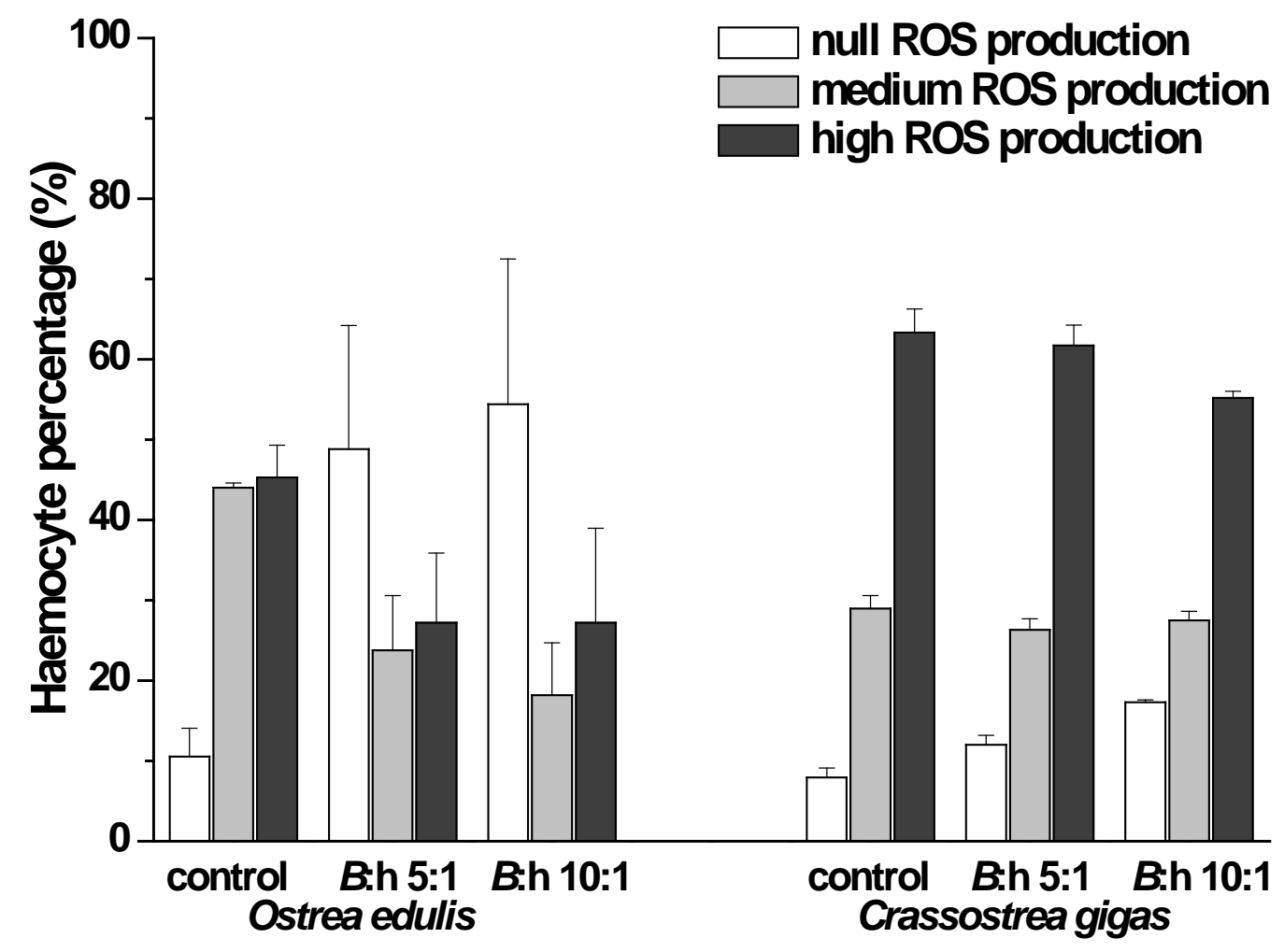

Fig. 8

Fig. 8. Distribution (percentage) of haemocyte of Ostrea edulis (left) and Crassostrea gigas (right) into classes of null, medium and high reactive oxygen species production, corresponding to three treatments: control, addition of $5 B$. ostreae cells per haemocyte (B:h 5:1), and addition of 10 B. ostreae cells per haemocyte (B:h 10:1). Bar height represents mean $( \pm S: E$.) percentage of cells. 